\title{
Metal concentrations in Unio pictorum mancus (Mollusca, Lamellibranchia) from of 12 Northern Italian lakes in relation to their trophic level
}

\author{
Oscar RAVERA*, Gian Maria BEONE ${ }^{1)}$, Roberto $\mathrm{CENCI}^{2)}$ and Paolo LODIGIANI ${ }^{1)}$ \\ C.N.R. Istituto per lo Studio degli Ecosistemi, L.go V. Tonolli 50, 28922 Verbania Pallanza, Italy \\ ${ }^{1)}$ Università Cattolica del Sacro Cuore, Istituto di Chimica Agraria e Ambientale, Via E. Parmense 84, 29100 Piacenza, Italy \\ ${ }^{2)}$ Istituto dell'Ambiente, CCR-E.C., 21020 Ispra (VA), Italy \\ *e-mail corresponding author: o.ravera@ise.cnr.it
}

\begin{abstract}
This research aims to test the reliability of environmental monitoring by bioaccumulators of pollutants; that is to establish a positive relationship between the pollutant concentrations in the bioaccumulator and those in the water in which it lives. To this end we analysed the contents of $\mathrm{Al}, \mathrm{Cu}, \mathrm{Zn}, \mathrm{Fe}, \mathrm{Mn}$ and $\mathrm{Ca}$ in the soft tissues and shell of Unio pictorum mancus. The filtered water samples from the mussel habitat were analysed for the same metals. The mussels were collected from 15 stations settled in 12 Northern Italian lakes during the first two weeks of July 2001. These results were obtained: a) metal concentrations varied widely with mussel size and among stations; b) a significant positive correlation between the concentration of calcium in the water and in the mussel tissues, but no relationship emerged for the other metals; c) no relationship between the metal concentrations in the tissues and those in the shell was found; d) there was a certain tendency for Mn, Fe and Zn concentrations in the soft tissues to increase with shell size; e) the sequence of the decreasing metal concentrations arranged for the tissues was similar to that of the shell, but rather different from that in the water; and f) the concentration factor values of the trace metals were high for the shell and soft tissues. In highly productive lakes large size mussels dominated, whereas small mussels were more abundant in low productive lakes. Although the metal concentrations in the water of productive lakes were greater than in low productive ones, the metal concentrations in the tissues of the mussels from the latter were generally higher than those in the mussels from the former. We propose some hypotheses to explain this paradox. Finally, our results show that the metal concentrations in the mussels do not reflect the metal concentrations in the water in which they live. It follows that this commonly used but oversimplified monitoring system cannot be recommended. On the other hand mussels may be very useful for other purposes, such as identifying new pollutants or pollutants present in such low concentrations that they cannot be measured with the commonly used methods. The pollutant content of mussels may enable the variations in time of the pollutant level of an environment to be monitored. In addition, the transplantation of mussels from a clean site to a polluted one may be a useful tool for identify the pollutants of the receiving environment.
\end{abstract}

Key words: Unionidae, biomonitoring, shell, soft tissues, size distribution, concentration factor, calcium, heavy metals

\section{INTRODUCTION}

Mussels have several characteristics which appear to indicate their use as biomonitors for estimating the environmental pollution level and the bioavailability of various types of pollutants (e.g. Crawford \& Luoma 1993; Metcalfe-Smith et al. 1996; Ravera 2001).

The most important example of the monitoring by mussels is the "Mussel Watch Programme" run by the NOAA (National Oceanic and Atmospheric Administration). Under the framework of this programme the Atlantic and Pacific coastal zones and many estuaries of the United States are monitored by analysing the pollutants accumulating in the soft tissues of sea mussels (e.g. Ferrington et al. 1983; O'Connor et al. 1994). Freshwater mussels are also used to evaluate the distribution and availability of trace metals, their radioisotopes and organic pollutants (e.g. Merlini et al. 1965; Czarnezki 1987; Riccardi \& Ravera 1989; Doherty et al. 1993; Oertel 1998; Ravera 2001), although biomonitoring by freshwater mussels has received far less attention than biomonitoring by marine species (Philipps \& Rainbow
1993). Several authors (e.g. Metcalfe-Smith et al. 1996) have discussed the possible causes of this difference and underlined the need for more research on freshwater mussels to be used as bioindicators (e.g. Metcalfe-Smith 1994; Metcalfe-Smith et al. 1996).

An earlier research compared the accumulation capacity of 15 trace elements by eight species of freshwater macrophytes and three species of mussels (Ravera et al. 2003). To exclude any influence either of the season or the physical environment, the materials were sampled at the same time in one habitat (Ranco Bay, Lago Maggiore, Northern Italy). In addition, to compare possible relationships between the trace element concentrations in macrophytes and mussels with those in their habitat the same elements were analized in water and surface sediment samples contemporarely collected at the same time from the same bay.

The results of this study, designed to compare the accumulation capacity of trace elements by various species, highlight the most suitable indicators for monitoring. In addition, by analysing the metals in mussels of different sizes, it was possible to evaluate the influence of age on metal accumulation. 


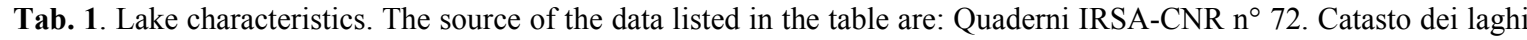
italiani. Volume I - Italia Settentrionale (Gaggino \& Cappelletti 1984) and Caratteristiche limnologiche dei laghi del Trentino - Rapporto 1998 (Corradini \& Flaim 1998) Istituto Agrario S. Michele all'Adige (Trento). ${ }^{\text {a) }}$ The water quality of Lake Levico, Lake Caldonazzo and Lake Segrino has improved since the 70s and these lakes are currently regarded as mesotrophic. Station 3 - Ranco; Station 4 - Sabbie d'Oro (Ispra); Station 7 - Parco; Station 8 - 200 m from Station 7; Station $11-1 \mathrm{~km}$ from the town of Mergozzo; Station 12 - Mergozzo camping site. $\mathrm{E}=$ eutrophic; $\mathrm{M}=$ mesotrophic; $\mathrm{O}$ $=$ oligotrophic; $\mathrm{O}-\mathrm{M}=$ oligotrophic and oligo-mesotrophic.

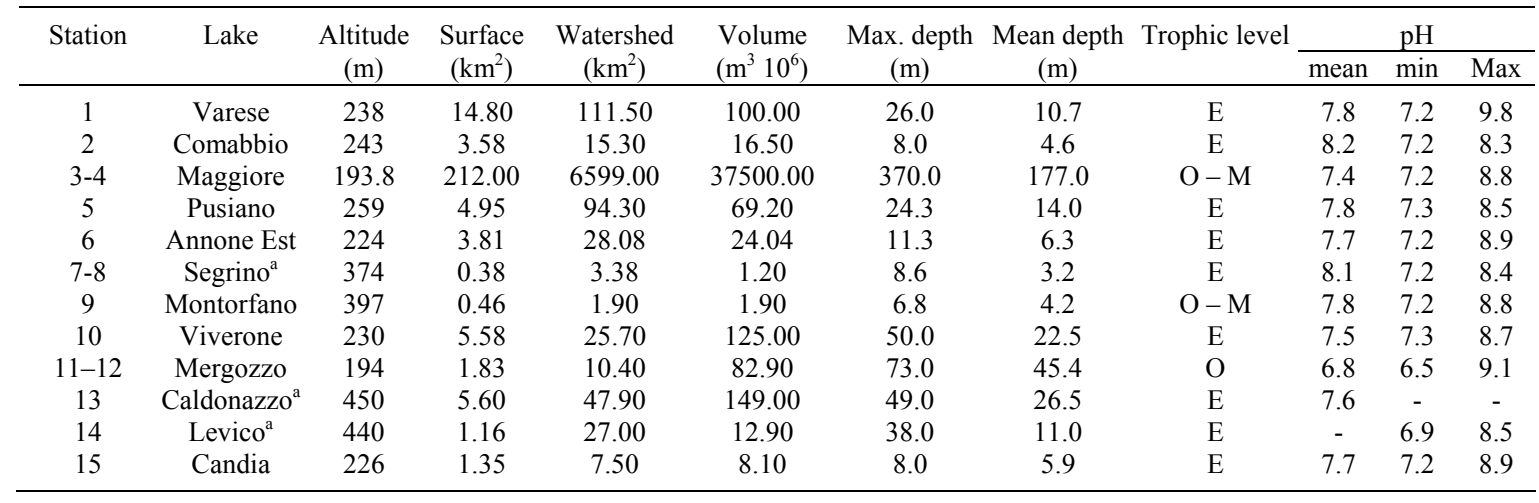

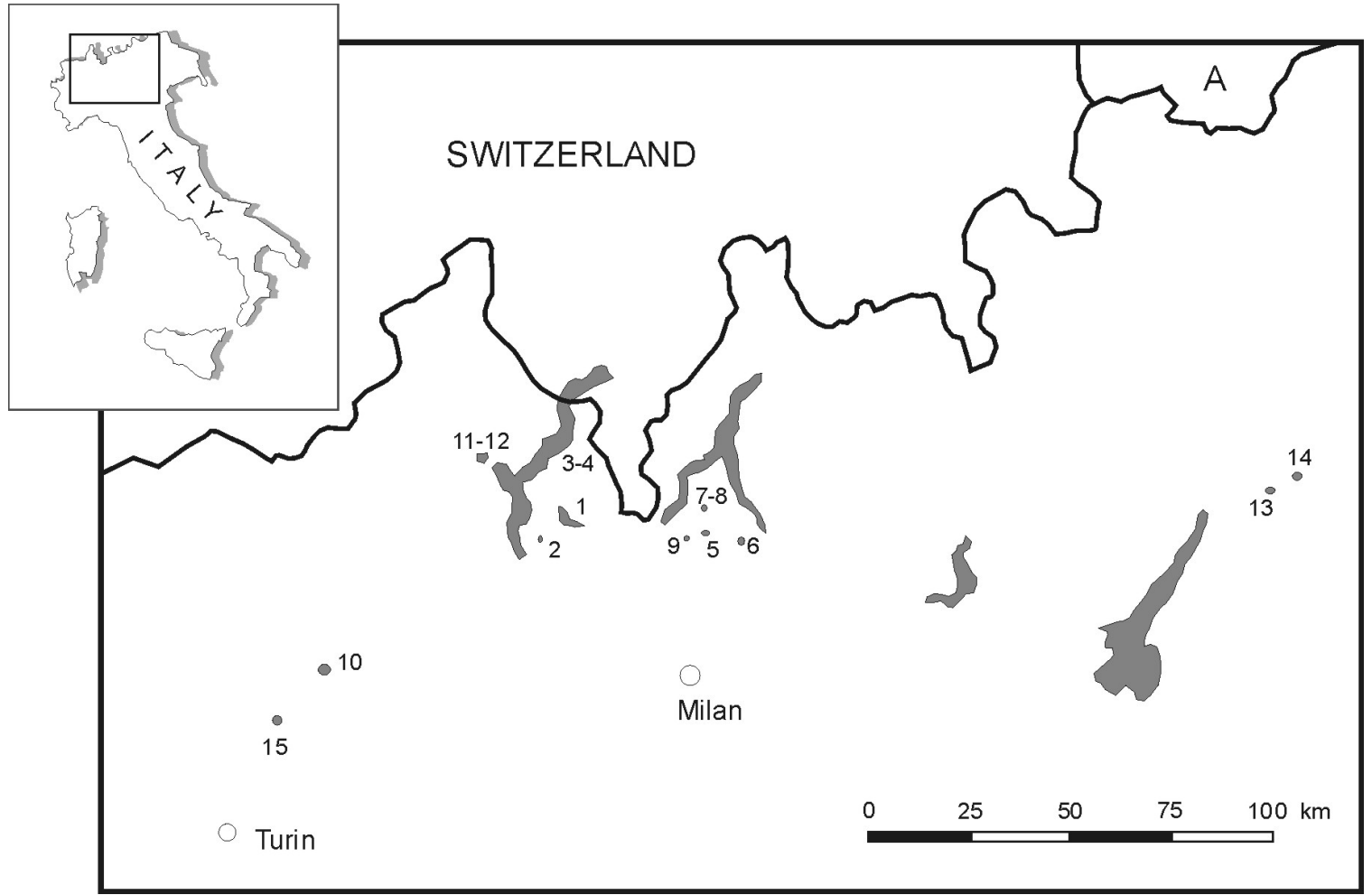

Fig. 1. Map of the sampled lakes.

On the other hand, the study did not yield any information on variations in the trace element concentrations in populations of the same species living in environments with various concentrations of the same elements.

\section{MATERIAL AND METHODS}

Samples of Unio pictorum mancus were collected from 12 lakes, with different morphometric and trophic characteristics distributed over a wide area of Northern
Italy: Piedmont, Lombardy and Trentino (Tab. 1, Fig. 1). All the material was collected during the first two weeks of July 2001.

Six elements (Al, $\mathrm{Cu}, \mathrm{Zn}, \mathrm{Fe}, \mathrm{Mn}, \mathrm{Ca})$ were analysed in samples of Unio shells and soft tissues from each population and water collected from their habitat.

The main reasons for our choosing these metals are as follows. Aluminium was analysed because little information on its distribution in mussel shell and soft tissues is available. Moreover, its physiological role is not 
known. The soil and sediments are the main sources of this metal. Its co-precipitating power is well known and this property makes it one of most effective substances for abating phosphorus in waste water treatment.

At low concentrations, copper is an essential element for organisms, but is toxic at high concentrations, so that its accumulation must be strictly regulated. At low concentrations zinc also plays an important role in physiology; it too is toxic at high concentrations, but to a lesser extent than copper.

The capacity of mussels (especially Unionidae) to concentrate manganese has been known for about a century (Bradley 1907a; 1907b). The highest concentrations were measured in the gills and mantle (e.g. Ravera \& Gaglione 1962; Gaglione \& Ravera 1964;). In the shell most of the manganese is tied up in organic matter encircling aragonite crystals of the nacreous layer (Nyström et al. 1996). Dissolved oxygen transforms the Mn oxide to bioxide, which in precipitating decreases the manganese concentration in the water, enriching the sediments with the metal. As for the high concentration of manganese in the soft tissues, Unionidae seem to accumulate an amount of manganese in excess of their needs.

Iron is another essential metal, generally abundant in any environment, and has several properties similar to those of manganese; for example, its partitioning between water and sediments is largely controlled by the oxygen concentration in the water.

Apart from calcium's major role in organism physiology, it is the most abundant metal in the shell and in the soft tissues. Its low affinity with chelating substances increases its availability to the organism. According to some authors (e.g. Markich \& Jeffree 1994), accumulation by the mussels of non-essential and even toxic metals my be explained by the Ca-influence on the uptake-rate of certain divalent, and trivalent metals.

At each station mussels were collected by hand from the littoral zone at a maximum depth of about 1 meter. Samples of water were taken from the same area, filtered on $0.45 \mu \mathrm{m}$ (pore size) Millipore filter and preserved in plastic bottles with the addition of some drops of nitric acid. The film of sediments and attached algae, coating the periostracum of the mussel shell was scrubbed off with a nylon nailbrush. The water bottles and the cleaned mussels, preserved in plastic bags, were placed on ice and rushed to the laboratory where they were refrigerated at $-20{ }^{\circ} \mathrm{C}$ until analysed. The mussels were frozen, without being allowed to clear their digestive tract, which would have eliminated undigested material and its content of elements. The advantages of this practice were discussed in a previous paper (Ravera et al. 2003). The mussels from each station were partially thawed and divided into six classes according to the length of their shell in: B (35-44 mm); C (45-54 mm); D (55-64 mm); E (65-74 mm); F (75-84 mm) and G (85$94 \mathrm{~mm}) .2$ to 6 classes were found at each station. No mussel shorter than $35 \mathrm{~mm}$ was collected. According to Patzner \& Müller (2001) it is very difficult to find juvenile mussels because of their small size and their burrowing way of life. For each station the soft tissues of the individuals of each length class, removed from their shells were pooled. The shells of the same mussels were also pooled, so that for each station the number of samples for analysis was twice the number of the length classes.

The soft tissues of the mussels were then freezedried and kept at $40{ }^{\circ} \mathrm{C}$ for 24 hours. The samples were pulverised by a Planetary Micro Mill in agate as well as the balls. The shells were broken up before pulverisation. The resulting powder was selected using a plastic sieve with $0.2 \mathrm{~mm}$ opening size. The shell and soft tissue samples were mineralised by a Micro Wave Digestion System CEM (Mattews, NC, USA) MDS-2000 model using $\mathrm{HNO}_{3}(65 \% \mathrm{~m} / \mathrm{v})$ and $\mathrm{H}_{2} \mathrm{O}_{2}(30 \% \mathrm{~m} / \mathrm{v})$ at $180{ }^{\circ} \mathrm{C}$ and a pressure of 1300 psi. The reagents were "Suprapur" (E. Merck, Darmstadt) High purity water was produced starting from distilled water using a Mill. QTM deionizing system (Millipore, Bedford, MA. USA). The solution obtained was filtered onto paper and analyzed for $\mathrm{Ca}, \mathrm{Al}, \mathrm{Cu}, \mathrm{Zn}, \mathrm{Fe}$ and $\mathrm{Mn}$ by ICPOESJY (Jobin Yvon Emission Horiba Group, Long Jumeau, Cedex, France) JY 24 model. These analyses were performed by G.M. Beone and co-workers (Istituto di Chimica Agraria e Ambientale, Università Cattolica del Sacro Cuore, Piacenza, Italy). The water samples were analyzed for the same metals by the Inductive Coupled Plasma - Mass Spectrometry (ICP-MS) by R.M. Cenci and co-workers (Institute of the Environment, Joint Research Center, E.C.Ispra, VA, Italy). The higher sensitivity of ICP-MS instrument allows measurement of the very low concentrations of metal (except calcium) in lake waters. Both instruments (ICP-AES and ICP-MS) are suitable for analysing the other properties.

A certified mussel tissue reference sample, CRM 278 (Mytilus edulis), prepared by the Community Bureau of Reference (BCR), was used to check the accuracy of the analytical procedure. The reliability of the analytical data is also demonstrated by the fact that concentrations of $\mathrm{Cu}, \mathrm{Zn}, \mathrm{Mn}$ and $\mathrm{Ca}$ in soft tissues and shell of $U$. pictorum mancus collected from station 3 (Ranco, Lago Maggiore) in 2001 were very similar to those of the same metals in the same species from the same station in 2000 (see tables 2a, 2b, 2d, 2e, 3a, 3b, $3 \mathrm{~d}$ and $3 \mathrm{e}$ in this paper and table 4 in Ravera et al. 2003).

\section{RESULTS}

The metal concentrations calculated for each station and length class in the soft tissues and shells are reported in tables 2, 2a, 2b, 2c, 2d, 2e and 3, 3a, 3b, 3c, 3d, 3e. 
Tab. 2. Aluminium concentration $\left(\mu \mathrm{g} \mathrm{g}^{-1} \mathrm{dw}\right)$ in the soft tissues. B, C, D, E, F, G = size classes. The range of each class is given in the text.

\begin{tabular}{ccccccccc}
\hline Station & $\mathrm{B}$ & $\mathrm{C}$ & $\mathrm{D}$ & $\mathrm{E}$ & $\mathrm{F}$ & $\mathrm{G}$ & mean & $\mathrm{SD}$ \\
\hline 9 & 233 & 334 & 97 & & & & 221.33 & 118.93 \\
8 & 466 & 204 & 97 & & & & 255.67 & 189.85 \\
6 & & 69 & 49 & 74 & & & 64.00 & 13.23 \\
1 & & 3 & 3 & & 1 & & 2.33 & 1.15 \\
4 & & 475 & 420 & 417 & 246 & & 389.50 & 99.31 \\
3 & & 363 & 472 & & & & 417.50 & \\
15 & 296 & & 154 & 206 & 60 & 30 & 149.20 & 108.36 \\
2 & & 13 & & 51 & 42 & & 35.33 & 19.86 \\
10 & & & & 373 & 356 & 446 & 391.67 & 47.82 \\
14 & & & & 3 & 361 & & 182.00 & \\
13 & & & & 491 & 420 & 539 & 483.33 & 59.87 \\
12 & & 708 & 404 & 494 & & & 535.33 & 156.16 \\
11 & & & 204 & 316 & & & 260.00 & \\
5 & & & 187 & 173 & 336 & 246 & 235.50 & 74.09 \\
7 & 487 & & 83 & 135 & & & 235.00 & 219.78 \\
mean & 370.50 & 271.13 & 197.27 & 248.45 & 227.75 & 315.25 & mean & SD \\
SD & 125.36 & 247.47 & 162.09 & 178.22 & 167.87 & 226.07 & 252.98 & \pm 183.77 \\
\hline
\end{tabular}

Tab. 2a. Copper concentration $\left(\mu \mathrm{g} \mathrm{g}^{-1} \mathrm{dw}\right)$ in the soft tissues.

\begin{tabular}{ccccccccc}
\hline Station & $\mathrm{B}$ & $\mathrm{C}$ & $\mathrm{D}$ & $\mathrm{E}$ & $\mathrm{F}$ & $\mathrm{G}$ & mean & $\mathrm{SD}$ \\
\hline 9 & 11 & 10 & 7 & & & & 9.33 & 2.08 \\
8 & 16 & 9 & 12 & & & & 12.33 & 3.51 \\
6 & & 17 & 8 & 10 & & & 11.67 & 4.73 \\
1 & & 9 & 12 & & 7 & & 9.33 & 2.52 \\
4 & & 82 & 86 & 90 & 38 & & 74.00 & 24.22 \\
3 & & 12 & 14 & & & & 13.00 & 1.41 \\
15 & 9 & 6 & 63 & 58 & 4 & 11 & 25.17 & 27.52 \\
2 & & 7 & & 8 & 10 & & 8.33 & 1.53 \\
10 & & & & 11 & 9 & 13 & 11.00 & 2.00 \\
14 & & & & & 25 & & 25.00 & \\
13 & & & & 17 & 11 & 11 & 13.00 & 3.46 \\
12 & & 21 & 20 & 19 & & & 20.00 & 1.00 \\
11 & & & 18 & 21 & & & 19.50 & 2.12 \\
5 & & & 13 & 10 & 9 & 7 & 9.75 & 2.50 \\
7 & 14 & & 7 & 9 & & & 10.00 & 3.61 \\
mean & 12.50 & 19.22 & 23.64 & 25.30 & 14.13 & 10.50 & mean & SD \\
SD & 3.11 & 24.03 & 26.00 & 27.12 & 11.47 & 2.52 & 19.37 & \pm 21.21 \\
\hline
\end{tabular}

Tab. 2b. Zinc concentration $\left(\mu \mathrm{g} \mathrm{g}^{-1} \mathrm{dw}\right)$ in the soft tissues.

\begin{tabular}{ccccccccc}
\hline Station & B & C & D & E & F & G & mean & SD \\
\hline 9 & 189 & 176 & 205 & & & & 190.00 & 14.53 \\
8 & 214 & 231 & 422 & & & & 289.00 & 115.49 \\
6 & & 346 & 307 & 559 & & & 404.00 & 135.64 \\
1 & & 176 & 192 & & 423 & & 263.67 & 138.22 \\
4 & & 632 & 949 & 791 & 1030 & & 850.50 & 176.26 \\
3 & & 343 & 374 & & & & 358.50 & \\
15 & 136 & 142 & 182 & & 426 & 1012 & 379.60 & 373.14 \\
2 & & 174 & & 376 & 481 & & 343.67 & 156.03 \\
10 & & & & 297 & 293 & 411 & 333.67 & 67.00 \\
14 & & & & 1118 & 925 & & 1021.50 & \\
13 & & & & 317 & 232 & 193 & 247.33 & 63.41 \\
12 & & 373 & 287 & 319 & & & 326.33 & 43.47 \\
11 & & & 268 & 267 & & & 267.50 & \\
5 & & & 205 & 327 & 515 & 465 & 378.00 & 140.08 \\
7 & 228 & & 289 & 377 & & & 298.00 & 74.91 \\
mean & 191.75 & 288.11 & 334.55 & 474.80 & 540.63 & 520.25 & mean & SD \\
SD & 40.52 & 155.96 & 217.59 & 276.07 & 286.60 & 348.28 & 395.52 & \pm 253.95 \\
\hline
\end{tabular}


Tab. 2c. Iron concentration $\left(\mu \mathrm{g} \mathrm{g}^{-1} \mathrm{dw}\right)$ in the soft tissues.

\begin{tabular}{ccccccccc}
\hline Station & $\mathrm{B}$ & $\mathrm{C}$ & $\mathrm{D}$ & $\mathrm{E}$ & $\mathrm{F}$ & $\mathrm{G}$ & mean & $\mathrm{SD}$ \\
\hline 9 & 863 & 6946 & 6465 & & & & 4758.00 & 3381.73 \\
8 & 4452 & 2088 & 3554 & & & & 3364.67 & 1193.32 \\
6 & & 907 & 1556 & 11236 & & & 4566.33 & 5785.21 \\
1 & & 16666 & 1532 & & 1568 & & 6588.67 & 8727.25 \\
4 & & 7436 & 4581 & 1715 & 2586 & & 4079.50 & 2538.96 \\
3 & & 2515 & 2157 & & & & 2336.00 & \\
15 & 1750 & 1771 & 3689 & 4121 & 5233 & 4206 & 3461.67 & 1411.82 \\
2 & & 447 & 166 & 1537 & 2315 & & 1125.25 & 999.36 \\
10 & & & & 2799 & 2193 & 3167 & 2719.67 & 491.82 \\
14 & & & & 6064 & 9445 & & 7754.50 & \\
13 & & & & 1788 & 2499 & 5043 & 3110.00 & 1711.36 \\
12 & & 1818 & 1856 & 4413 & & & 2695.67 & 1487.38 \\
11 & & & 1421 & 2860 & & & 2140.50 & \\
5 & & & 1517 & 2065 & 2588 & 2113 & 2070.75 & 438.18 \\
7 & 808 & & 1513 & 2561 & & & 1627.33 & 882.08 \\
mean & 1968.25 & 4510.44 & 2500.58 & 3745.00 & 3553.38 & 3632.25 & mean & SD \\
SD & 1711.18 & 5200.34 & 1744.84 & 2839.91 & 2614.19 & 1270.69 & 3388.02 & \pm 2998.82 \\
\hline
\end{tabular}

Tab. 2d. Manganese concentration $\left(\mu \mathrm{g} \mathrm{g}^{-1} \mathrm{dw}\right)$ in the soft tissues.

\begin{tabular}{ccccccccc}
\hline Station & $\mathrm{B}$ & $\mathrm{C}$ & $\mathrm{D}$ & $\mathrm{E}$ & $\mathrm{F}$ & $\mathrm{G}$ & mean & $\mathrm{SD}$ \\
\hline 9 & 2697 & 22289 & 20797 & & & & 15261.00 & 10906.29 \\
8 & 10874 & 7861 & 11344 & & & & 10026.33 & 1889.90 \\
6 & & 3569 & 5901 & 31958 & & & 13809.33 & 15760.40 \\
1 & & 4509 & 3865 & & 6590 & & 4988.00 & 1424.25 \\
4 & & 24816 & 16579 & 4358 & 6831 & & 13146.00 & 9400.05 \\
3 & & 4979 & 4957 & & & & 4968.00 & \\
15 & 2874 & 4147 & 8942 & 6337 & 9752 & 6345 & 6399.50 & 2653.80 \\
2 & & 1294 & 111 & 10486 & 13522 & & 6353.25 & 6659.14 \\
10 & & & & 4664 & 6090 & 7385 & 6046.33 & 1361.03 \\
14 & & & & 4998 & 7359 & & 6178.50 & \\
13 & & & & 5554 & 5864 & 6004 & 5807.33 & 230.29 \\
12 & & 2508 & 1820 & 3516 & & & 2614.67 & 853.02 \\
11 & & & 2057 & 2412 & & & 2234.50 & \\
5 & & & 3292 & 6797 & 9431 & 8240 & 6940.00 & 2659.79 \\
7 & 2300 & & 5128 & 7855 & & & 5094.33 & 2777.65 \\
mean & 4686.25 & 8441.33 & 7066.08 & 8085.00 & 8179.88 & 6993.50 & mean & SD \\
SD & 4132.14 & 8776.00 & 6294.96 & 8216.08 & 2600.19 & 1017.63 & 7538.71 & \pm 6322.96 \\
\hline
\end{tabular}

Tab. 2e. Calcium concentration $\left(\mu \mathrm{g} \mathrm{g}^{-1} \mathrm{dw}\right)$ in the soft tissues.

\begin{tabular}{ccccccccc}
\hline Station & B & C & D & E & F & G & mean & SD \\
\hline 9 & 29291 & 148008 & 98024 & & & & 91774.33 & 59604.74 \\
8 & 95825 & 54138 & 67992 & & & & 72651.67 & 21230.54 \\
6 & & 32095 & 44903 & 265062 & & & 114020.00 & 130962.88 \\
1 & & 40588 & 38483 & & 45767 & & 41612.67 & 3748.55 \\
4 & & 211141 & 155094 & 56640 & 74495 & & 124342.50 & 71990.82 \\
3 & & 42086 & 39649 & & & & 40867.50 & \\
15 & 15634 & 21193 & 36765 & 24552 & 38253 & 32454 & 28141.83 & 9086.35 \\
2 & & 6060 & 989 & 53624 & 71907 & & 33145.00 & 35068.92 \\
10 & & & & 40147 & 48072 & 57999 & 48739.33 & 8944.69 \\
14 & & & & 426 & 39619 & & 20022.50 & \\
13 & & & & 42812 & 39355 & 34988 & 39051.67 & 3920.81 \\
12 & & 23787 & 20737 & 36243 & & & 26922.33 & 8214.73 \\
11 & & & 24003 & 2333 & & & 23668.00 & \\
5 & & & 33624 & 55877 & 74796 & 67216 & 57878.25 & 17941.36 \\
7 & 21117 & & 32130 & 49770 & & & 34339.00 & 14453.66 \\
mean & 40466.75 & 64344.00 & 49366.08 & 58953.27 & 54033.00 & 48164.25 & mean & SD \\
SD & 37329.66 & 68608.36 & 41156.72 & 70438.64 & 16670.55 & 17128.12 & 54307.56 & \pm 49522.47 \\
\hline
\end{tabular}


Tab. 3. Aluminium concentration $\left(\mu \mathrm{g} \mathrm{g}^{-1} \mathrm{dw}\right)$ in the shell. $\mathrm{B}, \mathrm{C}, \mathrm{D}, \mathrm{E}, \mathrm{F}, \mathrm{G}=$ size classes. The range of each class is given in the text.

\begin{tabular}{ccccccccc}
\hline Station & $\mathrm{B}$ & $\mathrm{C}$ & $\mathrm{D}$ & $\mathrm{E}$ & $\mathrm{F}$ & $\mathrm{G}$ & mean & $\mathrm{SD}$ \\
\hline 9 & 94 & 99 & 2 & 2 & & & 49.25 & 54.60 \\
8 & 32 & 19 & 446 & & & & 165.67 & 242.86 \\
6 & & 61 & 24 & 158 & & & 81.00 & 69.20 \\
1 & & 33 & 15 & 39 & 7 & & 23.50 & 15.00 \\
4 & & 415 & 62 & 150 & 21 & & 162.00 & 177.04 \\
3 & & 50 & 46 & & & & 48.00 & \\
15 & 81 & 102 & 44 & 13 & 17 & 14 & 45.17 & 38.25 \\
2 & & 63 & 23 & 25 & 9 & & 30.00 & 23.12 \\
10 & & & & 21 & 13 & 7 & 13.67 & 7.02 \\
14 & & & & 121 & 305 & & 213.00 & \\
13 & & & & 4 & & 103 & 53.50 & \\
12 & & & 100 & & & & 100.00 & \\
11 & & & 120 & & & & 120.00 & \\
5 & & & 218 & 168 & & 33 & 139.67 & 95.70 \\
7 & 145 & & & 34 & & & 89.50 & \\
mean & 88.00 & 105.25 & 100.00 & 66.82 & 62.00 & 39.25 & mean & SD \\
SD & 46.44 & 128.42 & 130.41 & 67.19 & 119.16 & 43.90 & 80.86 & \pm 100.48 \\
\hline
\end{tabular}

Tab. 3a. Copper concentration $\left(\mu \mathrm{g} \mathrm{g}^{-1} \mathrm{dw}\right)$ in the shell.

\begin{tabular}{ccccccccc}
\hline Station & $\mathrm{B}$ & $\mathrm{C}$ & $\mathrm{D}$ & $\mathrm{E}$ & $\mathrm{F}$ & $\mathrm{G}$ & mean & $\mathrm{SD}$ \\
\hline 9 & 2.8 & 2.8 & 0.8 & 0.3 & & & 1.675 & 1.31 \\
8 & 0.8 & 2.4 & 3.6 & & & & 2.27 & 1.40 \\
6 & & 3.1 & 1.3 & 2.9 & & & 2.43 & 0.99 \\
1 & & 0.9 & 1.4 & 0.8 & 2.6 & & 1.43 & 0.83 \\
4 & & 3.6 & 3.3 & 2.4 & 2.5 & & 2.95 & 0.59 \\
3 & & 4.7 & 2.8 & & & & 3.75 & \\
15 & 1.1 & 1.3 & 14.7 & 1.6 & 0.9 & 1.6 & 3.53 & 5.48 \\
2 & & 1.7 & 1.5 & 1.9 & 2.2 & & 1.83 & 0.30 \\
10 & & & & 4.6 & 3.7 & 6.6 & 4.97 & 1.48 \\
14 & & & & 6.3 & 16.9 & & 11.60 & \\
13 & & & & 3.9 & & 3.6 & 3.75 & \\
12 & & & 7.8 & & & & 7.80 & \\
11 & & & 9.1 & & & & 9.10 & \\
5 & & & 3.4 & 3.6 & & 3.6 & 3.53 & 0.12 \\
7 & 3.6 & & & 4.1 & & & 3.85 & \\
mean & 2.08 & 2.56 & 4.52 & 2.95 & 4.80 & 3.85 & mean & SD \\
SD & 1.35 & 1.26 & 4.30 & 1.77 & 6.00 & 2.06 & 3.53 & \pm 3.29 \\
\hline
\end{tabular}

Tab. 3b. Zinc concentration $\left(\mu \mathrm{g} \mathrm{g}^{-1} \mathrm{dw}\right)$ in the shell.

\begin{tabular}{|c|c|c|c|c|c|c|c|c|}
\hline Station & B & $\mathrm{C}$ & $\mathrm{D}$ & $\mathrm{E}$ & $\mathrm{F}$ & G & mean & SD \\
\hline 9 & 22 & 27 & 21 & 25 & & & 23.75 & 2.75 \\
\hline 8 & 29 & 28 & 27 & & & & 28.00 & 1.00 \\
\hline 6 & & 18 & 20 & 20 & & & 19.33 & 1.15 \\
\hline 1 & & 19 & 23 & 31 & 22 & & 23.75 & 5.12 \\
\hline 4 & & 23 & 19 & 20 & 20 & & 20.50 & 1.73 \\
\hline 3 & & 24 & 21 & & & & 22.50 & \\
\hline 15 & 30 & 19 & 20 & 22 & 30 & 22 & 23.83 & 4.92 \\
\hline 2 & & 21 & 22 & 23 & 21 & & 21.75 & 0.96 \\
\hline 10 & & & & 7 & 26 & 14 & 15.67 & 9.61 \\
\hline 14 & & & & 38 & & & 38.00 & \\
\hline 13 & & & & 14 & & & 14.00 & \\
\hline 12 & & & 7 & & & & 7.00 & \\
\hline \multicolumn{9}{|l|}{11} \\
\hline 5 & & & 5 & 4 & & 21 & 10.00 & 9.54 \\
\hline 7 & 90 & & & 69 & & & 79.50 & \\
\hline mean & 42.75 & 22.38 & 18.50 & 24.82 & 23.80 & 19.00 & mean & SD \\
\hline $\mathrm{SD}$ & 31.70 & 3.78 & 6.96 & 17.58 & 4.15 & 4.36 & 24.00 & \pm 14.63 \\
\hline
\end{tabular}


Tab. 3c. Iron concentration $\left(\mu \mathrm{g} \mathrm{g}^{-1} \mathrm{dw}\right)$ in the shell.

\begin{tabular}{ccccccccc}
\hline Station & $\mathrm{B}$ & $\mathrm{C}$ & $\mathrm{D}$ & $\mathrm{E}$ & $\mathrm{F}$ & $\mathrm{G}$ & mean & $\mathrm{SD}$ \\
\hline 9 & 63 & 75 & 65 & 91 & & & 73.5 & 12.79 \\
8 & 129 & 62 & 376 & & & & 189.00 & 165.38 \\
6 & & 147 & 66 & 147 & & & 120.00 & 46.77 \\
1 & & 72 & 66 & 50 & 46 & & 58.50 & 12.48 \\
4 & & 227 & 62 & 110 & 47 & & 111.50 & 81.55 \\
3 & & 91 & 104 & & & & 97.50 & \\
15 & 120 & 127 & 319 & 396 & 498 & 558 & 336.33 & 184.26 \\
2 & & 93 & 57 & 58 & 74 & & 70.50 & 16.90 \\
10 & & & & 258 & 138 & 332 & 242.67 & 97.90 \\
14 & & & & 541 & 1492 & & 1016.50 & \\
13 & & & & 343 & & 1029 & 686.00 & \\
12 & & & 95 & & & & 95.00 & \\
11 & & & 87 & & & & 87.00 & \\
5 & & & 143 & 146 & & 136 & 141.67 & 5.13 \\
7 & 91 & & & 66 & & & 78.50 & \\
mean & 100.75 & 111.75 & 130.91 & 200.55 & 382.50 & 513.75 & mean & SD \\
SD & 29.94 & 54.70 & 110.69 & 162.74 & 570.10 & 384.35 & 211.20 & \pm 273.71 \\
\hline
\end{tabular}

Tab. 3d. Manganese concentration $\left(\mu \mathrm{g} \mathrm{g}^{-1} \mathrm{dw}\right)$ in the shell.

\begin{tabular}{ccccccccc}
\hline Station & $\mathrm{B}$ & $\mathrm{C}$ & $\mathrm{D}$ & $\mathrm{E}$ & $\mathrm{F}$ & $\mathrm{G}$ & mean & $\mathrm{SD}$ \\
\hline 9 & 542 & 579 & 860 & 916 & & & 724.25 & 191.06 \\
8 & 382 & 428 & 607 & & & & 472.33 & 118.87 \\
6 & & 275 & 416 & 422 & & & 371.00 & 83.19 \\
1 & & 299 & 232 & 298 & 378 & & 301.75 & 59.72 \\
4 & & 158 & 176 & 172 & 206 & & 178.00 & 20.20 \\
3 & & 203 & 242 & & & & 222.50 & \\
15 & 557 & 457 & 789 & 1138 & 1110 & 1006 & 842.83 & 289.34 \\
2 & & 379 & 428 & 540 & 605 & & 488.00 & 103.80 \\
10 & & & & 380 & 396 & 395 & 390.33 & 8.96 \\
14 & & & & 528 & 723 & & 625.50 & \\
13 & & & & 362 & & 576 & 469.00 & \\
12 & & & 200 & & & & 200.00 & \\
11 & & & 168 & & & & 168.00 & \\
5 & & & 206 & 279 & & 361 & 282.00 & 77.54 \\
7 & 322 & & & 611 & & & 466.50 & \\
mean & 450.75 & 347.25 & 393.09 & 513.27 & 569.67 & 584.50 & mean & SD \\
SD & 116.79 & 140.13 & 253.20 & 288.03 & 321.21 & 296.42 & 461.52 & \pm 252.67 \\
\hline
\end{tabular}

Tab. 3e. Calcium concentration $\left(\mathrm{mg} \mathrm{g}^{-1} \mathrm{dw}\right)$ in the shell.

\begin{tabular}{ccccccccc}
\hline Station & $\mathrm{B}$ & $\mathrm{C}$ & $\mathrm{D}$ & $\mathrm{E}$ & $\mathrm{F}$ & $\mathrm{G}$ & mean & $\mathrm{SD}$ \\
\hline 9 & 413 & 403 & 399 & 392 & & & 401.75 & 8.77 \\
8 & 397 & 403 & 383 & & & & 394.33 & 10.26 \\
6 & & 368 & 389 & 380 & & & 379.00 & 10.54 \\
1 & & 408 & 379 & 402 & 389 & & 394.50 & 13.03 \\
4 & & 384 & 402 & 404 & 396 & & 396.50 & 9.00 \\
3 & & 394 & 396 & & & & 395.00 & \\
15 & 405 & 381 & 398 & 406 & 396 & 405 & 398.50 & 9.52 \\
2 & & 406 & 391 & 405 & 369 & & 392.75 & 17.25 \\
10 & & & & 364 & 340 & 322 & 342.00 & 21.07 \\
14 & & & & 349 & 352 & & 350.50 & \\
13 & & & & 323 & & 348 & 335.50 & \\
12 & & & 321 & & & & 321.00 & \\
11 & & & 341 & & & & 341.00 & \\
5 & & & 375 & 368 & & 363 & 368.67 & 6.03 \\
7 & 378 & & & 457 & & & 417.50 & \\
mean & 398.25 & 393.38 & 379.45 & 386.36 & 373.67 & 359.50 & mean & SD \\
SD & 15.00 & 14.36 & 25.81 & 35.49 & 23.91 & 34.74 & 382.82 & \pm 27.55 \\
\hline
\end{tabular}


Tab. 4. Mean metal concentration and standard deviation (SD), variation coefficient (\% $\mathrm{VC}$ ) and number of analysed samples $\left(\mathrm{N}^{\circ}\right)$. Mean values are expressed in $\mu \mathrm{g} \mathrm{g}^{-1} \mathrm{dw}$, except that of $\mathrm{Ca}$ in the shell expressed in $\mathrm{mg} \mathrm{g}^{-1} \mathrm{dw}$. The data in this table were calculated on all the values listed in tables 2 and 3 .

\begin{tabular}{lccccccc}
\hline & \multicolumn{3}{c}{ soft tissues } & & \multicolumn{3}{c}{ shell } \\
\cline { 2 - 5 } \cline { 6 - 8 } & mean \& SD & $\% \mathrm{VC}$ & $\mathrm{N}^{\circ}$ & & mean \& SD & \% VC & $\mathrm{N}^{\circ}$ \\
\hline $\mathrm{Al}$ & $252.98 \pm 183.77$ & 73 & 46 & & $80.86 \pm 100.48$ & 124 & 44 \\
$\mathrm{Cu}$ & $19.37 \pm 21.21$ & 109 & 46 & & $3.53 \pm 3.29$ & 93 & 44 \\
$\mathrm{Zn}$ & $395.52 \pm 253.95$ & 64 & 46 & & $24.00 \pm 14.63$ & 61 & 42 \\
$\mathrm{Fe}$ & $3388.02 \pm 2998.82$ & 88 & 48 & & $211.20 \pm 273.71$ & 130 & 44 \\
$\mathrm{Mn}$ & $7538.71 \pm 6322.96$ & 84 & 48 & & $461.52 \pm 252.67$ & 55 & 44 \\
$\mathrm{Ca}$ & $54307.56 \pm 49522.47$ & 91 & 48 & & $382.82 \pm 27.55$ & 7 & 44 \\
\hline
\end{tabular}

Tab. 5. Metal concentration in the filtered water $(0.45 \mu \mathrm{m}$ pore size $)$ concentrations are expressed in $\mu \mathrm{gl}^{-1}$, except for calcium which is expressed in $\mathrm{mg} \mathrm{l}^{-1}$.

\begin{tabular}{ccccccc}
\hline Station & $\mathrm{Al}$ & $\mathrm{Cu}$ & $\mathrm{Zn}$ & $\mathrm{Fe}$ & $\mathrm{Mn}$ & $\mathrm{Ca}$ \\
\hline 1 & 5.70 & 1.03 & 7.03 & 94.0 & 2.19 & 20.27 \\
2 & 4.60 & 0.99 & 10.50 & 80.0 & 6.18 & 9.48 \\
3 & 11.10 & 1.06 & 17.60 & 78.0 & 1.47 & 13.99 \\
4 & 24.90 & 1.50 & 35.30 & 61.0 & 10.40 & 13.41 \\
5 & 2.30 & 0.94 & 10.50 & 15.0 & 4.18 & 14.25 \\
6 & 3.00 & 0.60 & 7.50 & 33.0 & 2.48 & 33.28 \\
7 & 1.60 & 0.45 & 31.50 & 61.4 & 1.14 & 28.11 \\
8 & 6.30 & 0.60 & 4.68 & 1.7 & 1.42 & 34.45 \\
9 & 11.60 & 0.70 & 3.63 & 8.2 & 2.28 & 21.39 \\
10 & 734 & 1.58 & 14.60 & 12.4 & 2.29 & 14.49 \\
11 & 259 & 0.91 & 10.80 & 16.1 & 0.92 & 4.31 \\
12 & 44.60 & 0.85 & 6.97 & 24.7 & 0.53 & 3.43 \\
13 & 184 & 1.56 & 12.21 & 75.3 & 9.88 & 16.98 \\
14 & 24.10 & 1.01 & 10.90 & 26.7 & 2.20 & 21.15 \\
15 & 166 & 0.76 & 86.85 & 25.5 & 7.84 & 10.21 \\
\hline
\end{tabular}

Table 4 lists the mean concentrations of metals in the soft tissues and shells calculated for all stations and length classes. These values highlight the fact that the $\mathrm{Ca}$ concentration in the shell is seven times that calculated for the soft tissues, whereas the concentrations of the other metals are higher in the tissues than those in the shells: three times higher for $\mathrm{Al}$, five times for $\mathrm{Cu}$ and sixteen times for $\mathrm{Zn}, \mathrm{Fe}$ and $\mathrm{Mn}$. Because of the high values of the standard deviation (SD) compared to those of the mean, it seemed interesting to calculate the variation coefficient $(\%$ V.C. $=\mathrm{SD} /$ mean $\times 100)$ for each metal in the soft tissues and shell. The VC values, except for those of $\mathrm{Ca}$ in the shell, are very high and for $\mathrm{Cu}$ in the tissues and $\mathrm{Al}$ and $\mathrm{Fe}$ in the shell the values are higher than 100 , i.e. the standard deviation is greater than the mean (Tab. 4).

The sequences of the mean trace metal concentrations arranged in order of decreasing concentration for filtered water (Tab. 5), soft tissues and shells from the 15 stations are the following:

- For water: $\mathrm{Al}(45 \%)>\mathrm{Fe}(35 \%)>\mathrm{Zn}(15 \%)>\mathrm{Mn}(3 \%)>$ $>\mathrm{Cu}(0.83 \%)$

- For shell: $\operatorname{Mn}(59 \%)>\mathrm{Fe}(25 \%)>\operatorname{Al}(12 \%)>\mathrm{Zn}(3 \%)>$ $>\mathrm{Cu}(0.54 \%)$

- For soft tissues: $\mathrm{Mn}(65 \%)>\mathrm{Fe}(28 \%)>\mathrm{Zn}(3 \%)>$ $>\mathrm{Al}(2 \%)>\mathrm{Cu}(0.18 \%)$
The figures in brackets are the mean percentages of the trace metals. To get more homogenous samples, we used the data referring to the mussels of length classes $\mathrm{D}$ and $\mathrm{E}(55-74 \mathrm{~mm})$, which are those with the highest number of specimens. Because the macroelement calcium is always the most abundant metal the water, in the shell and soft tissues, it was not taken into consideration in the sequences of trace metals. After calcium, aluminium is the most abundant metal in the water, with manganese most abundant in the shell and soft tissues.

Interestingly, the sequence in the shell is very similar to that in the soft tissues, except for aluminium which is concentrated more in the shell than in the tissues. The sequence in the water is rather different from the sequences both in the shell and in the tissues, suggesting that mussels have an effective capacity to select metals.

In addition, the sequences of metals in water, shell and tissues were drawn up for each station. The concentration of aluminium in the water as well as in the tissues and shells shows great variability, so that in the sequences for the same compartment (e.g. shell, tissues, water) of the different stations it may fill different places in the sequence. Because of this, and because this metal does not play a physiological role, aluminium was not taken into account in the sequences of the stations. If the $\mathrm{Al}$ is excluded, the sequences for the water of 11 
stations, those for the shells of 12 stations and those for tissues of 13 stations were identical to the sequences corresponding to the water, shell and tissues based on the mean values of the 15 stations reported above. These sequences were observed in most of the stations, but in a few of them the sequences were different due to the exceedingly high concentrations of one metal. For the water, in stations 8,10 and $15 \mathrm{Zn}$ concentration was higher than that of $\mathrm{Fe}$ and in station $12 \mathrm{Cu}$ was higher than Mn. For the shell, in the station $14 \mathrm{Fe}$ concentration was higher than that of $\mathrm{Mn}$, in station $12 \mathrm{Cu}$ was higher than $\mathrm{Zn}$ and in station $7 \mathrm{Zn}$ was higher than Fe. For the soft tissues, in stations 12 and 14 Fe concentration was higher than that of Mn.

A positive relationship between $\mathrm{Ca}$ concentrations in the water of the lakes and those in the soft tissues from the same environments was evident (Fig. 2). Conversely, no negative relationship between trace metal concentrations in the tissues and $\mathrm{Ca}$ concentration in the water was observed. No relationship for $\mathrm{Mn}, \mathrm{Fe}$ and $\mathrm{Zn}$ was noted and only a tendency for $\mathrm{Cu}$ and $\mathrm{Al}$ concentrations to increase in the tissues at low $\mathrm{Ca}$ concentrations in the water was found.

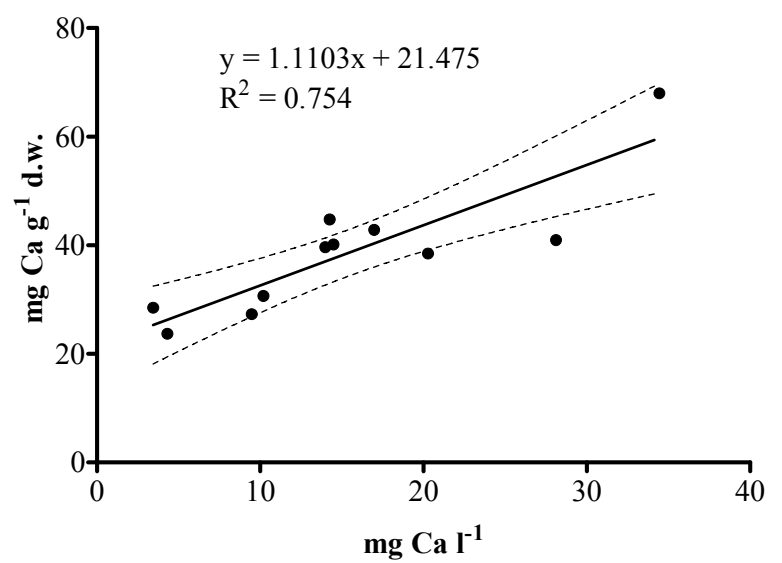

Fig. 2. Relationship between calcium concentrations in filtered lake water and in mussel soft tissues.

For each station the percentage of mussels belonging to each length class showed that in 7 stations $(3,4,6,7$, $8,9,12$ ) the smaller specimens (belonging to length classes B, C and D) were more abundant than those in the other 8 stations $(1,2,5,10,11,13,14,15)$, where larger individuals (E, F and $\mathrm{G}$ classes) were more frequent (Fig. 3). In fact, in the 7 stations more than $60 \%$ of the specimens were $<65 \mathrm{~mm}$ and less than $40 \%$ greater than $65 \mathrm{~mm}$; conversely in the other 8 stations more than $60 \%$ of the mussels were $>65 \mathrm{~mm}$ and less than $40 \%<65 \mathrm{~mm}$.

Because shell length increases with age, the demographic structure of the populations of the 7 stations (group A) is different from that of the populations of the 8 stations (group B). With this in mind it seemed interesting to ascertain if there was a relationship between the demographical structure of a population (directly or indirectly influenced by the physical environment) and the mean concentration of metals in the soft tissues of the mussels of the two groups of populations (A and B).

Because the results may be influenced by the different capacity for accumulating metals by individuals of different size (e.g. Boyden 1977; Strong \& Luoma 1981; Popham \& D'Auria 1983; Brix \& Lyngby 1985); the homogeneity of the samples is essential. Consequently, only the metal concentrations in the mussels belonging to classes $\mathrm{D}$ and $\mathrm{E}(55-74 \mathrm{~mm})$ were considered.

The results (Tab. 6) showed clearly that the mean concentration of metals in the tissues of the mussels of group A are always higher than those of B group; the greatest differences were observed for $\mathrm{Al}, \mathrm{Fe}$ and $\mathrm{Mn}$ and the smallest for $\mathrm{Cu}$ and $\mathrm{Zn}$. The mean concentration of metals in the water of the stations in group $\mathrm{A}$ is always lower than that of group B, except for the Ca concentration, which in the water of the group $\mathrm{A}$ is higher than that of group B. Therefore, the metal concentrations in the tissues of mussels do not reflect the concentrations of the metal in the water. For example, Mn concentration in the tissues of mussels of group $\mathrm{A}$ is more than twice that calculated for group B, although the concentration of the same metal in the water of the group B is 1.6 times than that of group A. Aluminium concentration in the tissues of the group $\mathrm{A}$ is greater than that of the B group, but the Al concentration in the water of the group $B$ is 16 times higher than that in the water of group A.

To obtain a better information on this relationship, for each station the metal concentrations in the tissues were compared with those in the water. No relationship for $\mathrm{Al}, \mathrm{Cu}, \mathrm{Fe}$ and $\mathrm{Zn}$ was found for the stations of groups $\mathrm{A}$ and $\mathrm{B}$ and only a weak relationship for $\mathrm{Ca}$ and $\mathrm{Mn}$ for the stations of the $\mathrm{B}$ group. The mean concentrations of $\mathrm{Al}, \mathrm{Zn}, \mathrm{Mn}$ and $\mathrm{Ca}$ in the shell of group A are higher than those of the group $\mathrm{B}$, while concentrations of $\mathrm{Cu}$, and particularly of $\mathrm{Fe}$, are higher in group $\mathrm{B}$ than those calculated for group A. As stated above for the tissues, no relationship emerged between metal concentrations in the shell and those in the water.

Of the seven stations of the group A one was located in a eutrophic lake (Lake Annone), two in a mesotrophic lake (Lake Segrino), four in oligo-mesotrophic lakes (Lago Maggiore and Lake Montorfano) and one in the oligotrophic Lake Mergozzo. Of the eight stations of the group B five were located in eutrophic lakes (Lake Varese, Lake Comabbio, Lake Pusiano, Lake Viverone, Lake Candia), two in lakes (Lake Levico and Lake Caldonazzo) which two decades ago were eutrophic and now are considered mesotrophic and only one (Lake Mergozzo) is oligotrophic (Tab. 1).

In conclusion, the group A stations are generally in lakes with low production, those of group B in lakes with middle and high trophic levels. 

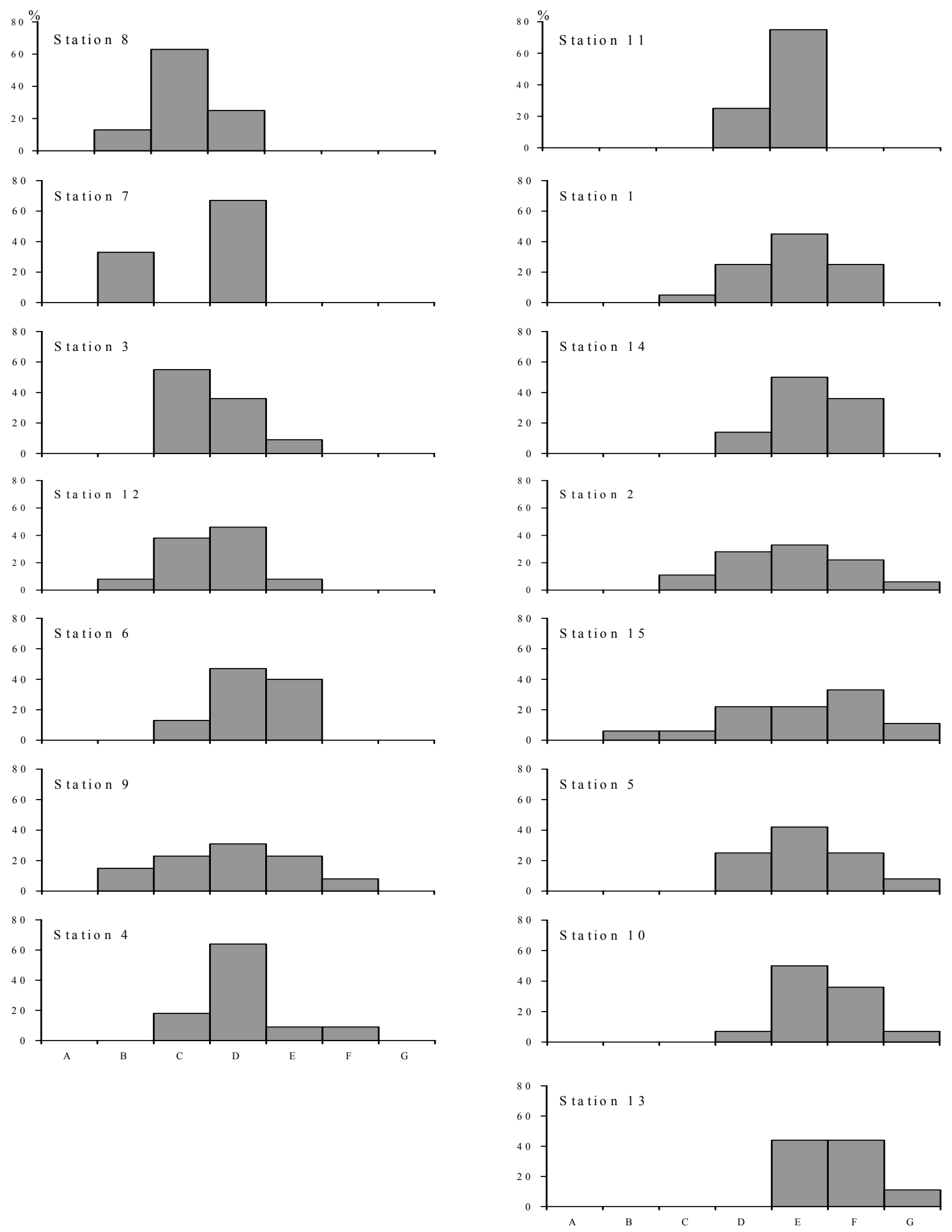

Fig. 3. Percent size distribution of the mussels in the size classes (shell length) from the 15 stations. 
Tab. 6. Mean metal concentrations in the soft tissues, shell and water from 7 stations of the group $\mathrm{A}\left(\mathrm{N}^{\circ} 3,4,6,7,8,9,12\right)$ and 8 of the group $\mathrm{B}\left(\mathrm{N}^{\circ} 1,2,5,10,11,13,14,15\right)$. The concentrations in the soft tissues and shell are expressed in $\mu \mathrm{g} \mathrm{g}^{-1} \mathrm{dw}$, except those of calcium in the shell $\left(\mathrm{mg} \mathrm{g}^{-1} \mathrm{dw}\right)$. The concentrations in the water are expressed in $\mu \mathrm{g} \cdot \mathrm{l}^{-1}$. Only the mussels belonging to the size-classes $\mathrm{D}$ and $\mathrm{E}$ were considered.

\begin{tabular}{cccccccc}
\hline Group & & $\mathrm{Al}$ & $\mathrm{Cu}$ & $\mathrm{Zn}$ & $\mathrm{Fe}$ & $\mathrm{Mn}$ & $\mathrm{Ca}$ \\
\hline \multirow{4}{*}{$\mathrm{A}$} & tissues & 244 & 23 & 420 & 3842 & 10808 & 76565 \\
& shell & 118 & 3 & 27 & 130 & 449 & 391 \\
& water & 15 & 1 & 15 & 38 & 3 & 21 \\
& & & & & & & \\
\multirow{4}{*}{ B } & tissues & 199 & 20 & 405 & 2611 & 4912 & 31032 \\
& shell & 67 & 5 & 19 & 231 & 424 & 367 \\
& water & 172 & 1 & 20 & 43 & 4 & 14 \\
\hline
\end{tabular}

Tab. 7. Mean metal concentrations in the soft tissues, shell and water from 5 stations $\left(\mathrm{N}^{\circ} 3,4\right.$, $9,11,12)$ settled in oligo- and oligo-mesotrophic lakes $(\mathrm{O}), 4$ stations $\left(\mathrm{N}^{\circ} 7,8,13,14\right)$ in mesotrophic lakes $(\mathrm{M})$ and 6 stations $\left(\mathrm{N}^{\circ} 1,2,5,6,10,15\right)$ in eutrophic lakes (E). The concentrations in the soft tissues and shell are expressed in $\mu \mathrm{g} \mathrm{g}^{-1} \mathrm{dw}$, except those of calcium in the shell $\left(\mathrm{mg} \mathrm{g}^{-1} \mathrm{dw}\right)$. The concentrations in the water are expressed in $\mu \mathrm{g}^{-1}$. Only the mussels belonging to the size-classes $\mathrm{D}$ and $\mathrm{E}$ were considered.

\begin{tabular}{|c|c|c|c|c|c|c|c|}
\hline & & $\mathrm{Al}$ & $\mathrm{Cu}$ & $\mathrm{Zn}$ & $\mathrm{Fe}$ & $\mathrm{Mn}$ & $\mathrm{Ca}$ \\
\hline \multirow{3}{*}{$\mathrm{O}$} & tissues & 339 & 30 & 404 & 3409 & 8225 & 59140 \\
\hline & shell & 75 & 5 & 17 & 90 & 335 & 371 \\
\hline & water & 70 & 1 & 15 & 38 & 3 & 11 \\
\hline \multirow{3}{*}{ M } & tissues & 175 & 12 & 547 & 3361 & 7094 & 38045 \\
\hline & shell & 151 & 4 & 37 & 331 & 527 & 378 \\
\hline & water & 54 & 1 & 15 & 41 & 4 & 25 \\
\hline \multirow{3}{*}{$\mathrm{E}$} & tissues & 141 & 19 & 313 & 2882 & 7574 & 56055 \\
\hline & shell & 64 & 3 & 17 & 163 & 459 & 385 \\
\hline & water & 153 & 1 & 23 & 43 & 4 & 17 \\
\hline
\end{tabular}

The considerations outlined above suggest that the trophic level of the lake may (albeit indirectly) influence the demographic structure of the mussel populations as well as the capacity of the mussels to accumulate metals in their tissues. Moreover, it cannot be ruled out that demographic characteristics, influenced by the trophic level of the environment, may in their turn effect the mussels' capacity for accumulating metals.

To ascertain the relationship between metal concentrations in the mussels and the trophic level of the lake in which they live, the 15 stations were divided into three groups reflecting the trophic level of the lake where the station was located: a) oligotrophic and oligomesotrophic (stations: 3, 4, 9, 11, 12); b) mesotrophic (stations: 7, 8, 13, 14) and c) eutrophic (stations: 1, 2, 5, 6, 10, 15). Interesting, the genus Anodonta was present only in the mesotrophic and eutrophic stations.

Table 7 shows the mean metal concentrations in the soft tissues and the shells of the mussels (length classes $\mathrm{D}$ and E) collected from the stations of the three groups, a), b), and c). The same table lists the mean metal concentrations in the waters of the three groups. Apart from zinc, which has a higher concentration in the tissues of mussels from mesotrophic lakes, the other five metals are more concentrated in the tissues of mussels from oligotrophic and oligo-mesotrophic lakes than in those from eutrophic and mesotrophic lakes.

The metals enrichment in the tissues of mussels from low productive lakes cannot be due to an abundance of metals in the water, because the metal concentrations in the oligotrophic and oligo-mesotrophic lakes are lower than those measured in the mesotrophic and eutrophic ones. Copper is the sole exception, with the same mean concentration in the water of the three groups of lakes $\left(0.9 \mu \mathrm{g} \mathrm{l}^{-1}\right)$. A comparison between high productive and low productive lakes shows clearly that in the latter the metal concentrations are lower in the water and higher in the mussel tissues.

There is no clear relationship between metal concentrations in the tissues and those in the water of the three groups of lakes. The differences between the mean concentrations of copper in the shell of the three groups of lakes are negligible, while the concentrations of the other five metals are higher in the shells from the mesotrophic and eutrophic lakes than those from the oligotrophic and oligo-mesotrophic lakes.

In conclusion, the pattern of metal concentrations in the shell is very different from that of the tissues; this is true for populations with a different demographic structure (groups A and B) as well as for populations 
Tab. 8. Trace metal concentrations ( $\mu \mathrm{g} \mathrm{g}^{-1} \mathrm{dw}$ ) and Ca concentrations ( $\mu \mathrm{g} \mathrm{g}^{-1} \mathrm{dw}$ for tissues and $\mathrm{mg} \mathrm{g}^{-1} \mathrm{dw}$ in for shell) in mussels belonging to different size classes $(\mathrm{B}, \mathrm{C}, \mathrm{D}, \mathrm{E}, \mathrm{F}, \mathrm{G})$. The mussels were collected from Lake Candia.

\begin{tabular}{cccccccc}
\hline & & $\mathrm{Al}$ & $\mathrm{Cu}$ & $\mathrm{Zn}$ & $\mathrm{Fe}$ & $\mathrm{Mn}$ & $\mathrm{Ca}$ \\
\hline \multirow{5}{*}{ soft } & $\mathrm{B}$ & 296 & 9 & 136 & 1750 & 2874 & 15634 \\
tissues & $\mathrm{C}$ & 10608 & 6 & 142 & 1771 & 4147 & 21193 \\
& $\mathrm{D}$ & 154 & 63 & 182 & 3689 & 8942 & 36765 \\
& $\mathrm{E}$ & 206 & 58 & - & 4121 & 6337 & 24552 \\
& $\mathrm{~F}$ & 60 & 4 & 426 & 5233 & 9752 & 38253 \\
& $\mathrm{G}$ & 30 & 11 & 1012 & 4206 & 6345 & 32454 \\
& & & & & & & \\
shell & $\mathrm{B}$ & 81 & 1 & 30 & 120 & 557 & 405 \\
& $\mathrm{C}$ & 102 & 1 & 19 & 127 & 457 & 381 \\
& $\mathrm{D}$ & 44 & 15 & 20 & 319 & 789 & 398 \\
& $\mathrm{E}$ & 13 & 2 & 22 & 396 & 1138 & 406 \\
& $\mathrm{~F}$ & 17 & 1 & 30 & 498 & 1110 & 396 \\
& $\mathrm{G}$ & 14 & 2 & 22 & 558 & 1006 & 405 \\
\hline
\end{tabular}

living in lakes with different trophic levels. These differences are due to both the metabolism and the pathway of metals in the shell, which are very different from those in the soft tissues.

In the same population, individuals of larger size are likely to be older than those of smaller size. In this connection, we compared the metal concentrations in the tissues of mussels with their shell length to ascertain if there is a relationship between the age of the mussel and the metal accumulation in its tissues. We used the mussels from station 15 (Lake Candia), which had the only population with sufficient mussel biomass for each length class to permit chemical analyses.

The data reported in table 8 reveal a certain tendency of $\mathrm{Mn}, \mathrm{Fe}, \mathrm{Zn}$ and $\mathrm{Ca}$ concentrations in the soft tissues to increase with the size of the mussel, but the correlation was significative only for Fe (Fig. 4). No relationship emerged for $\mathrm{Cu}$ and $\mathrm{Al}$; the former probably due to its low concentration and Al because it cannot be metabolized. In the shell $\mathrm{Fe}$ and Mn concentrations were significatively correlated with mussel size, a tendency which is not evident for $\mathrm{Ca}, \mathrm{Cu}$ and $\mathrm{Al}$.

To evaluate the capacity of the mussel to concentrate in its tissues metals from a diluted solution of lake water the concentration factors (C.F.) were calculated. C.F. is the value of the ratio between the concentration of a metal in the tissues, expressed in terms of the wet weight, and the concentration of the same metal in filtered water. The concentrations in the soft tissues calculated on the dry weight must therefore be transformed into concentrations on the wet weight by dividing the value by 5.38 (Ravera et al. 2003). To minimise the influence of mussel size and to obtain more homogeneous values, only the concentrations in mussel tissue from length classes $\mathrm{D}$ and $\mathrm{E}$ were considered.

The mean values of the C.F. for each metal and the 15 stations are the following: $\mathrm{Al}=3615 ; \mathrm{Cu}=4143 ; \mathrm{Zn}$ $=7444 ; \mathrm{Fe}=51,634 ; \mathrm{Mn}=651,065$ and $\mathrm{Ca}=709$. The high C.F. for Mn is the result of the low concentration of this metal in the water and the great capacity of the Unionidae to concentrate $\mathrm{Mn}$ in their tissues.
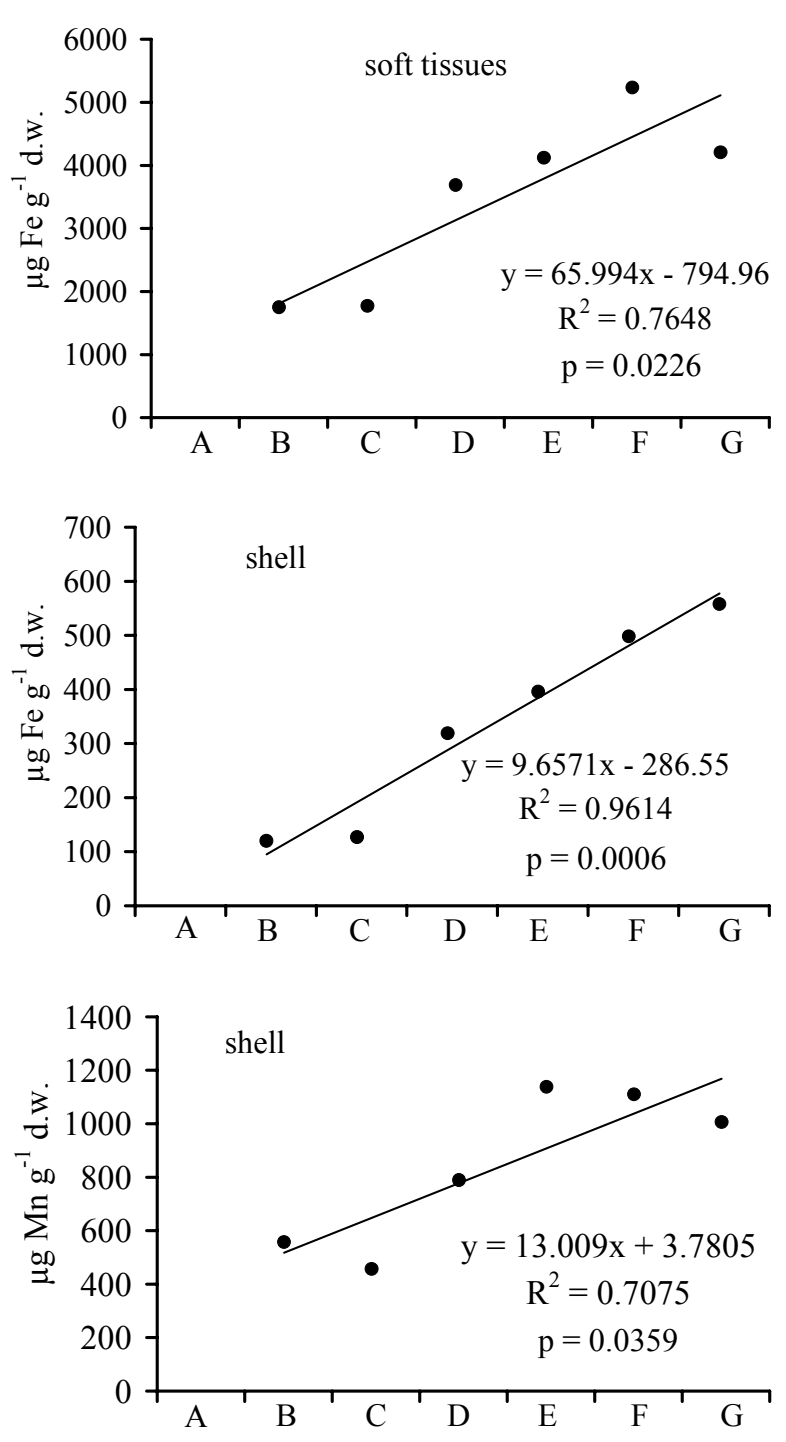

Fig. 4. Significative correlation between Fe concentrations in the soft tissues of mussels and their size classes and between $\mathrm{Fe}$ and $\mathrm{Mn}$ concentrations in the shell of mussels and their size classes. $\mathrm{B}=35-44 \mathrm{~mm} ; \mathrm{C}=45-54 \mathrm{~mm} ; \mathrm{D}=55-64 \mathrm{~mm} ; \mathrm{E}=$ $65-74 \mathrm{~mm} ; \mathrm{F}=75-84 \mathrm{~mm} ; \mathrm{G}=85-94 \mathrm{~mm}$. 
Tab. 9. Concentration factors (C.F.) of metals in mussels belonging to the size classes D and E. Upper C.F. of mussels (soft tissues) from the stations of the group A ( $\mathrm{N}^{\circ}$ station: 3, 4, 7 , $8,9,12)$ and the group B ( $\mathrm{N}^{\circ}$ station: $\left.1,2,5,10,11,13,14,15\right)$. Down - C.F. of mussels (soft tissues) from stations $\left(\mathrm{N}^{\circ} 3,4,9,11,12\right)$ settled in oligotrophic-oligo-mesotrophic lakes $(\mathrm{O})$ from stations $\left(\mathrm{N}^{\circ} 7,8,13,14\right)$ in mesotrophic lakes $(\mathrm{M})$ and from stations $\left(\mathrm{N}^{\circ} 1,2\right.$, $5,6,10,15)$ in eutrophic lakes $(\mathrm{E})$.

\begin{tabular}{ccccccc}
\hline Group & $\mathrm{Al}$ & $\mathrm{Cu}$ & $\mathrm{Zn}$ & $\mathrm{Fe}$ & $\mathrm{Mn}$ & $\mathrm{Ca}$ \\
\hline $\mathrm{A}$ & 5216 & 4259 & 9461 & 86486 & 1072140 & 842 \\
$\mathrm{~B}$ & 2215 & 4027 & 6491 & 21141 & 282625 & 577 \\
& & & & & & \\
$\mathrm{O}$ & 3464 & 4817 & 8272 & 41593 & 788715 & 1082 \\
M & 4013 & 3018 & 10661 & 108195 & 782944 & 369 \\
$\mathrm{E}$ & 3476 & 4144 & 5533 & 22297 & 448438 & 569 \\
\hline
\end{tabular}

The mean values of the C.F. calculated for the stations of group A are higher than those of group B (Tab. 9). If the metal concentration in the tissues is fairly constant and the concentration of the same metal in the water is low, the C.F. value increases. This may explain the high C.F. values in group $\mathrm{A}$ for $\mathrm{Al}, \mathrm{Cu}$ and $\mathrm{Zn}$, but not for $\mathrm{Mn}, \mathrm{Fe}$ and $\mathrm{Ca}$. In fact, the C.F. values for $\mathrm{Fe}$ and $\mathrm{Mn}$ in $\mathrm{A}$ are 4 times those calculated for $\mathrm{B}$, whereas the $\mathrm{Fe}$ concentrations in the water of $\mathrm{B}$ are about the same as those in the water of $\mathrm{A}$; that of $\mathrm{Mn}$ in $\mathrm{B}$ is 1.5 times that of $\mathrm{A}$. Ca concentration in the water of $\mathrm{A}$ is very high compared with that of B and in the tissues of A the concentration is 2.5 times that in B. The C.F. values for $\mathrm{Fe}, \mathrm{Mn}$ and $\mathrm{Ca}$, higher in $\mathrm{A}$ than in $\mathrm{B}$, are probably not the consequence of the different concentrations of these metals in the water, but are probably due to the fact that the mussels of group A have a greater capacity for accumulating metals than the mussels of group B, or because of the greater availability of metal forms in the lakes of group A.

The influence of the trophic level of the lakes on the C.F. values varies with the metal (Tab. 9). In fact, the highest values for $\mathrm{Cu}, \mathrm{Mn}$ and $\mathrm{Ca}$ were calculated in the stations of the oligotrophic and oligo-mesotrophic lakes and for $\mathrm{Al}, \mathrm{Zn}$ and $\mathrm{Fe}$ in the mesotrophic lakes, whereas the values for the eutrophic lakes are generally low.

\section{DISCUSSION AND CONCLUSIONS}

The primary aim of this research was to compare the concentrations of some metals in soft tissues of Unio pictorum mancus (Unionidae) from 12 different lakes with the concentrations of the same metals in the lake waters. This comparison forms the basis of the biomonitoring method which uses species accumulators of pollutants.

The metal concentrations in the soft tissues should reflect the present level of the water contamination by the same metals, while those in the shell the time-integrated metal contamination of the environment. This difference is due to the metabolic turnover time, which is very slow for the shell and relatively rapid for the soft tissues.
Time integration is commonly considered an advantage by the advocates of this type of monitoring. It is undoubtedly an advantage if the pollution history of the environment can be reconstructed by analysing the pollutants in the layers of the shell. Unfortunately, studies on this subject are rather scarce because of the difficulties of the methods (e.g. Nelson 1964; Clark 1980; McCuaig \& Green 1983; Day 1984; Carell et al. 1987; Nyström \& Dunca 1996; Westermark et al. 1996; Mutvei \& Westermark 2001). If, on the other hand, the shell is analysed in toto time integration cannot be an advantage because the pollutants accumulated in the past together with the more recent ones cannot reflect either the present environmental situation or that of the past. For this reason our main aim in analysing the shell was not to establish a relationship between the metal concentrations in the shell and those in the water, but to compare the metal concentrations in the shell with those in the soft tissues.

Mussels take up elements from the water and with food, and a fraction of these is accumulated in the soft tissues. A part of the metabolised elements is transferred from the mantle to the shell. A certain amount of the elements present in the shell is adsorbed from the water onto the periostracum, which is colonized by a film of bacteria, algae, protozoa and other small organisms. These organisms may play an important role on the shell; for example, according Chipman \& Schommers (1968) the bacterial activity on the periostracum controls the manganese concentration in the shell.

Mussels were collected over two weeks during the growing season (Summer) from 12 lakes located in the same ranges of latitude and altitude during two weeks to reduce to a minimum the seasonal influence on the metal concentrations in the mussels. In fact, this influence, the combined result of the biological cycle and the seasonal variations of the physical environment, may be considerable (Bryan 1973; Metcalfe-Smith 1994; Nyström et al. 1996).

From the measurement of the shell length of all the specimens it was clear that the small mussels were more frequent in some stations, while large ones were relatively more abundant in others. The maximum size at- 
tained by mussels is determined by the resources of their environment; over this limit growth is very slow or negligible (Seed 1968). In fact, the stations with a greater number of small individuals were those in less productive lakes, while large individuals were commoner in more productive lakes. This difference may be due to the different abundance and availability of food, which consists of suspended organic particles (e.g. algae), which are generally more abundant in productive than in low productive lakes. The higher mean concentrations of metal in the mussels from oligotrophic and oligo-mesotrophic lakes than in those from mesotrophic and eutrophic lakes are more difficult to explain.

In fact, this difference was due neither to mussel size, because only the medium-sized individuals (55-74 $\mathrm{mm}$ ) were considered nor to the metal concentrations in the water, because these were higher in productive than low productive lakes. Bryan (1973) observed a decrease of metal concentrations in the tissues of marine bivalves during periods of high phytoplankton density, and an increase when the phytoplankton density was low. The rapid reproduction of the phytoplankton caused a decrease of the metal concentrations in the water and a low concentration of metals in the algal cells due to biological dilution. As a result the bivalves feed on phytoplankton poor in metals so that the metal concentrations in their tissues were low. In contrast, the low density of phytoplankton richer in metals was the cause of the high concentrations of metals in the bivalve tissues.

Another possible cause may be the more abundant metals in available forms in the oligotrophic and oligomesotrophic lakes than in mesotrophic and eutrophic lakes. Unfortunately, this hypothesis cannot be tested because our analyses are of the total metals and not their physical and chemical species (Zamuda \& Sunda 1982).

There may be another cause. In an low productive lake, the low concentration of suspended particles (e.g. phytoplankton), which constitute the mussels' food, may reduce the growth-rate of the molluscs. As a result, mussels of the same size might be older in low productive than in productive lakes, and so have had more time to accumulate metals in their tissues. To test this hypothesis the absolute age of the mussels must be known. Dating mussels which live at Southern European latitudes is more difficult than it is for those from the Northern areas (e.g. Scandinavia), where the long cold winter suspends shell growth, producing a welldefined dark growth line on the external surface of the shell. Another cause of the high concentration of metal in mussels from low productive lakes may be their greater capacity to accumulate metals in their bodies.

In conclusion, the trophic level of the environment appears to have a considerable impact on the biometrical structure of the population as well as on metal accumulation in mussel tissues.
These hypotheses, or interactions between them, may explain the quantitative differences of metal accumulation in mussels from lakes with different trophic levels; unfortunately, the reliability of these hypotheses cannot be demonstrated by this study. Although on the basis of our data, the importance of the lake's trophic level seems to be clear, the variables responsible for the different accumulation of metals in mussels from lakes with different trophic levels cannot be identified. This is the usual difficulty with field studies, which have to cope with the complexity of the ecosystem. For example, eutrophic lakes always have high concentrations of suspended particles, which on their surface rapidly adsorb ionic metals, the metal most available form to aquatic organisms (Spry \& Wiener 1991). By metal adsorption onto the particles, metal sedimentation is accelerated and concentrations in the water decrease. On the other hand, if a lower concentration of ionic metals in the water is available, mussels take up a greater amount of metals with the particles ingested as a food. In addition, a fairly important influence on metal concentrations in the water is constituted by iron and manganese co-precipitating with other metals in the presence of oxygen (e.g. Markich \& Joffree 1994).

The detoxification processes studied in several species of mussels work through the production of calcium phosphate granules (Jeffree et al. 1993; Naimo 1995; Adams \& Shorey 1998; Langston et al. 1998; Byrne 2000) and/or thioneins (es. Roesijadi 1992; High et al. 1997). The granules and thioneins sequester the excess of metals uptaken by the mussel and abolish their potential toxic effects, which may explain the relatively high concentrations of toxic metals in the mussels.

Although mussels acquire a certain percentage of their calcium in food, most of the content of this metal in their tissues, and then in the shell, is uptaken through the gills from the water (e.g. Pynnönen 1991). Calcium, with its relatively low affinity for chelating substances, is generally present in the water in forms available to the organisms (Förstner \& Wittmann 1983).

In their laboratory experiments, on mussels Markich \& Jeffree (1994) observed two very interesting effects deriving from the increase of the $\mathrm{Ca}$ concentration in the water: a) the Ca uptake-rate increases and b) there is a considerable reduction of divalent trace metals in the tissues through competition for sites at the calcium channel. Result b) means that the divalent (and also some trivalent) trace metals follow the same metabolic pathway as calcium from water to the mussel. This may explain why mussels also uptake and accumulate nonessential and toxic elements in their bodies.

Our data show clear evidence of a relationship between the $\mathrm{Ca}$ concentrations in the water of the various lakes and those in the tissues of mussels from the same lakes (Fig. 2). Conversely, no relationship was observed for $\mathrm{Mn}, \mathrm{Zn}$ and $\mathrm{Fe}$, and there was a certain tendency for the $\mathrm{Cu}$ and $\mathrm{Al}$ concentrations in the tissues to increase at 
low concentrations of $\mathrm{Ca}$ in the water. This partial contrast with Markich and Joffree's results is probably due to the different media in which the studies were carried out. These authors' research was short-term and was carried out in the laboratory with "artificial water" contaminated by prefixed amounts of trace metals, mostly in ionic form. Our research was carried out in natural waters containing suspended particles, colloids and chelating substances (Winner 1986), in addition to the metals in various physical-chemical forms.

In conclusion, the metal body burden of a mussel is controlled by the metal concentrations in the water and food, the amount of available forms of the metal, the selective capacity of the mussel, and its metabolic rate, which in turn, is influenced by the physical environment. The combined influence of these variables controls the relationship between the metal concentration in the mussel tissues and that in the water in which it lives.

In our case, establishing this relationship is very difficult because the influence of the physical environment on the metal concentration in the mussels varies with the lake. In addition, the populations of the same mussel species living in various lakes may have developed different capacities for selecting and accumulating metals by adaptation and selection processes.

At the same depth, the pelagic environment is fairly homogeneous compared to the littoral zone. The littoral may show more or less important differences along the lake perimeter, which is directly exposed to the various influences from the watershed. These differences increase with the sinuosity of the lake perimeter. This may explain the differences in metal concentrations in the tissues of mussels collected from different stations in the same lake. For example, in the oligotrophic Lake Mergozzo (stations 11 and 12) the differences between stations, except in the case of aluminium, are smaller than those in the oligo-mesotrophic Lago Maggiore (stations 3 and 4) and the mesotrophic Lake Segrino (stations 7 and 8) for iron, manganese and aluminium.

The metal concentration in an organism reflects that in the water in which it lives if the ratio between the metal concentration in the organism and that in the water is constant or at least similar. This means that the organism has very little or no capacity to select the metals to be uptaken. Such an ideal indicator species does not exist. A simple approach to test discrimination capacity consists in comparing the sequence of the metals arranged in order of decreasing concentration for the water with the sequence for mussel soft tissues and shell.

Our data highlight the similarity of the sequences of the soft tissues with those of the shell and the wide difference between both of these and the sequence of the metals in the water. This comparison shows that it is very difficult to evaluate the metal contamination in the water from the concentration of the metals in the mussels. Other authors have encountered the same difficul- ties (e.g. Johnson et al. 1993). Moreover, the capacity of mussels to discriminate between metals is quite clear, although this capacity is less effective than that developed by other, more evolved taxa, such as fish (Metcalfe-Smith et al. 1996).

A major drawback of using mussels as biomonitors of pollutants is their wide variability in concentrating the pollutants, even in individuals of the same size from the same population (e.g. Bryan 1973; Millington \& Walker 1983; Metcalfe-Smith et al. 1996).

These are the most important conclusions drawn from this study:

a) small sized mussels dominate in low productive lakes, whereas in productive lakes large sized mussels are dominant. According to some authors (e.g. Buddensiek et al. 1993; Patzner \& Müller 2001), only the oldest mussels may survive in very trophic environments, as they are less sensitive than the juveniles. It is obvious that these populations are fated to the extinction;

b) in spite of the lower concentrations of trace metals in the water, the metal concentrations in the tissues of mussels living in low productive lakes are higher than those in the mussels (belonging to the same size class) living in productive lakes, which have higher metal concentrations in the water;

c) a direct, positive relationship between calcium concentration in the water and in the tissues of mussels has been established;

d) no relationship between trace metal concentrations in the soft tissues and in the shell has been found.

The implications of $b$ ) are that the trace metal concentrations in the soft tissues do not reflect those measured in the water of the environment in which the mussels live. As an example, figure 5 is a schematic representation of the relationship between the manganese concentrations in the soft tissues of mussels from the 15 stations and those measured in the water form the same stations. The result, at least in our study, is that mussels cannot be regarded as reliable bioindicators for predicting the contamination level of their environment; which is the essential aim of routine biomonitoring. This may be due to the fact that, in our study, there were no lake with extreme differences in metal pollution levels. As is noted above, other authors (e.g. Johnson et al. 1993; Metcalfe-Smith et al. 1996) have found a similar difficulty with using mussels as a pollutant indicator.

On the other hand, if differences among physical environments are taken into account (e.g. available forms of metal concentrations, the quality and quantity of mussel food and its concentrations of available metals), and the different reactions from the various populations of a species to the same environmental variables are considered, a clear relationship between the metal concentrations in the filtered water and those in the mussel tissues might be difficulty expected. 


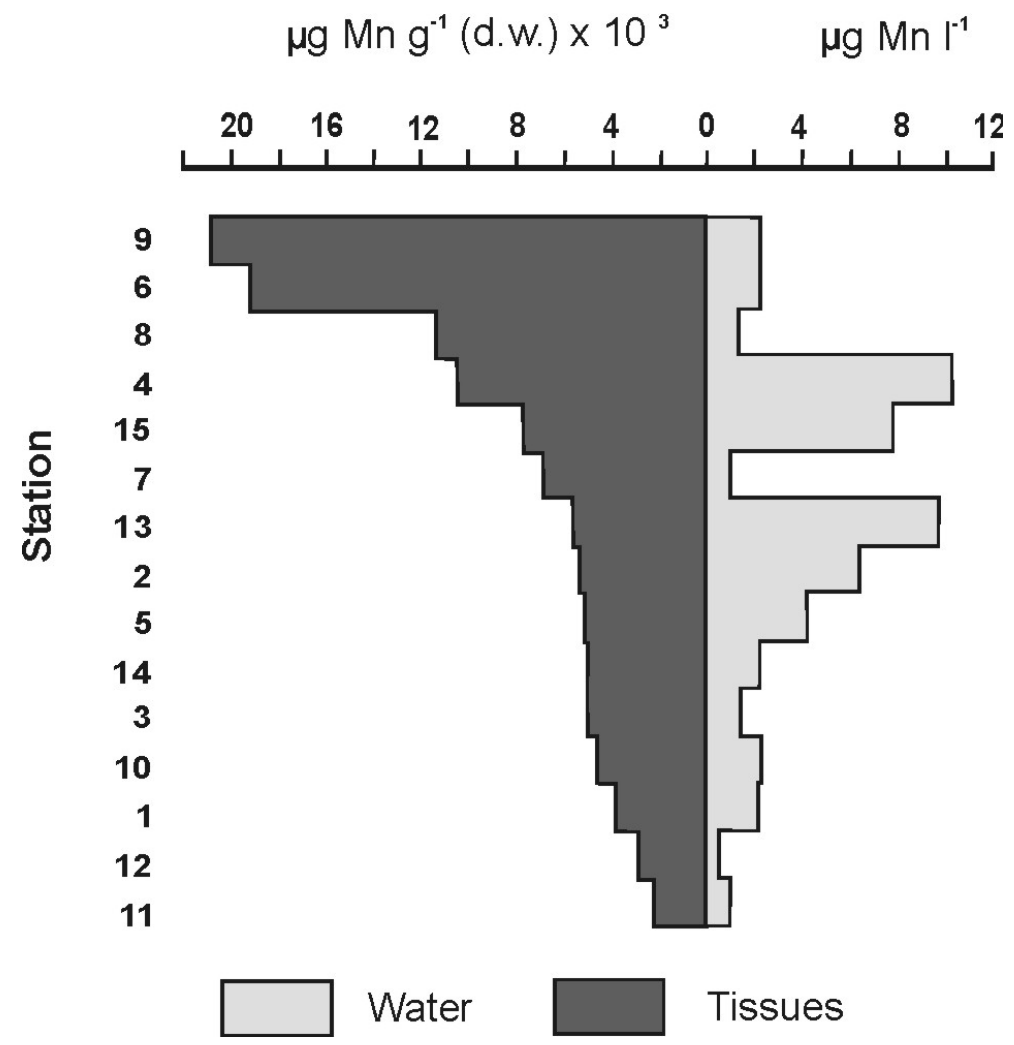

Fig. 5. Manganese concentrations in the tissues of mussels $\left(\mu \mathrm{g} \mathrm{g}^{-1} \mathrm{dw}\right)$ and in the water $\left(\mu \mathrm{g}^{-1}\right)$ of the 15 stations. To minimize the possible influence of mussel size, all the specimens taken into account ranged from $55 \mathrm{~mm}$ to $74 \mathrm{~mm}$ length (size classes: $\mathrm{D}$ and E).

In addition, the most commonly used mussel monitoring technique consist in analysing samples of mussel tissues and water collected at the same time from the same stations. This means that the water analyses reflect the situation at the moment of sampling, whereas those of the soft tissues is the result of integrating present and past situations, which depends on the biological turnover time of the metals in the tissues in relation to variations of the metal concentrations in the water. Although the turnover time of metals in the tissues is very short compared with that in the shell, it undoubtedly has an influence on the comparison between metal concentrations in the water and the tissues.

These considerations, which refer to the oversimplified type of monitoring commonly used, do not mean that the mussels are not excellent material for monitoring focusing on well-identified problems. First of all, in addition to the biological factors influencing the uptake and accumulation of pollutants in the organism, the environmental variables acting on the abundance and availability of the pollutants must be taken into account.

Some examples of the use of mussels for pollution monitoring are given below.

The transplantation of mussels from a clean site to a polluted one may be a useful tool for identifying the pollutants present in the polluted site and for following the kinetics of the pollutant uptake (e.g. Andres et al. 1999; Baudrimont et al. 1999; Furely \& Oliveira Filho
2000). In addition, transferring the contaminated mussels back to their original, clean site can be used to follow the pollutant loss over time.

Mussel analyses may be used to identify new pollutants in the environment and to follow their load variations over time. This was the method first used to detect Mn-54 from the fall-out of nuclear tests in the Pacific area in Europe in 1960, when mussels from two lakes in Northern Italy, Lago Maggiore and Lake Varese, were analysed (Ravera \& Vido 1961). At that time, the Mn54 activity was so low that it could not be measured in any aquatic organism (e.g. aquatic plants, gastropods, fish) except mussels (Unio and Anodonta). Variations in Mn-54 activity from September 1960 to December 1963 were also monitored by analysing its activity in mussels from Lago Maggiore (Gaglione \& Ravera 1964). The distribution in lakes and rivers of Northern Italy of the fission products (Cs-134 and Cs-137) from the fall-out of the Chernobyl accident was also studied through analyses on mussels (Riccardi \& Ravera 1986).

Since shell chemistry roughly reflects that of the water in which the mussels live, important information on past environmental conditions may by acquired by studying the shell (e.g. Carell et al. 1987; Westermark et al. 1996). For the same purpose, the chemical composition of shells of living mussels was compared to that of shells from museum collections. The results of this comparison were very interesting and involved a variety 
of topics such as acidification, eutrophication and metal pollution (Mutvei \& Westermark 2001).

Long term variations of pollutant concentrations in an environment may be monitoring by analysing the tissues of a mussel population, taking into account both the variations with the season and mussel size. To establish a relationship between the pollutant concentrations in the mussels and those in their environment, the pollutants in the water, sediment and suspended particles must be also analysed. This long term monitoring may produce better and more useful results than oversimplified short term monitoring.

\section{ACKNOWLEDGMENTS}

We are grateful to M. Matthieu Delaunag (Université de Toulon et du Var, France) for his help with the chemical analyses, and to Dr. Marta Dantas (Università di Venezia) and Mme Lorena Giannoni for their help in the preparation of the biological samples. We are also indebted to Dr. Nicoletta Riccardi for valuable help in collecting the biological material.

\section{REFERENCES}

Adams, S.M. \& C.D. Shorey. 1998. Energy dispersive spectroscopy of granular concretions in the mantle of the freshwater mussel Hyridella depressa from Lake Burragorang as a technique to monitoring metals in aquatic systems. Aquatic Toxicol., 44: 93-102.

Andres, S., M. Baudrimont, Y. Lapaquellerie, F. Ribeyre, N. Maillet, C. Latouche \& A. Boudou. 1999. Field transplantation of the freshwater bivalve Corbicula fluminea along a polymetallic contamination gradient (River Lot, France). I. Geochemical characteristics of the sampling sites and cadmium and zinc bioaccumulation kinetics. Environ. Toxicol. Chem., 18: 2462-2471.

Baudrímont, M., S. Andres, J. Metivaud, Y. Lapaquelleríe, F. Ribeyre, N. Maillet, C. Latouche \& A. Boudou. 1999. Field transplantation of the freshwater bivalve Corbicula fluminea along a polymetallic contamination gradient (River Lot, France). II Metallothioneins response to metal exposure. Environ. Toxicol. Chem., 18: 2472-2477.

Boyden, C.R. 1977. Effect of size upon metal content of shellfish. J. Mar. Bio. Assoc. U.K., 57: 675-714.

Bradley, H.C. 1907a. The occurrence of manganese in freshwater clams. Science, 25: 456.

Bradley, H.C. 1907b. Manganese. A normal element in the tissues of freshwater clams, Unio and Anodonta. J. Biol. Chem., 3: 151.

Bryan, G.W. 1973. The occurrence and seasonal variation of trace metals in the scallops Pecten maximus and Chlamys opercularis. J. Mar. Biol. Assoc. U.K., 53: 145-166.

Brix, H. \& J.E. Lyngby, 1985. The influence of size upon the concentration of $\mathrm{Cd}, \mathrm{Cr}, \mathrm{Cu}, \mathrm{Hg}, \mathrm{Pn}$ and $\mathrm{Zn}$ in the common mussel (Mytilus edulis, L.). Symp. Biol. Hung., 29: 253-271.

Buddensiek, V., H. Engel, S. Fleischauer-Rössing \& K. Wächtler. 1993. Studies on the chemistry of interstitial water taken from defined horizons in the fine sediments of bivalve habitats in several northern German lowland waters. Arch. Hydrobiol., 127: 151-166.

Byrne, M. 2000. Calcium concentrations in the interstitial tissues of the Australian freshwater mussel Hyridella depressa (Hyriidae). In: E.M. Harper, J.D. Taylor \& J.A. Crame (Eds). The evolutionary Biology of the Bivalvia. Special Publication. Geological Society, London, 177.
Carell, B., S. Forberg, E. Grundelius, L. Enrikson, A. Johnels, U. Lindh, H. Mutvei, M. Olsson, K. Svärdström, \& T. Westermark. 1987. Can mussel shells reveal environmental history? Ambio, 16: 2-10.

Chipman, W. \& E. Schommers. 1968. Role of surface associated organisms in the uptake in the radioactive manganese by the clam Tapes decussatus Radioactivity in the Sea. IAEA Publ., 24: $11 \mathrm{pp}$.

Clark, G.R. 1980. Study of molluscan shell structure and growth lines using thin sections. In: D.C. Rhoads \& R.A. Lutz (Eds). Skeletal growth of aquatic organisms. Biological records of environmental change. Plenum Press, New York: 600-606.

Corradini, F. \& G. Flaim. 1998. Caratteristiche limnologiche dei laghi del Trentino. Rapporto Istituto Agrario S. Michele all'Adige.

Crawford, J.K. \& S.N. Luona. 1993. Guidelines for studies of contaminants in biological tissues for the National Water - Quality Assessment Program. U.S. Geological Service Open-File Rep. N ${ }^{\circ}$ 92-494. Denver, Co. USA.

Czarnezki, J.M. 1987. Use of the pockebook mussel Lampsilis ventricosa for monitoring heavy metal pollution in an Ozark stream. Bull. Environ. Contam. Toxicol., 38: 641646.

Day, M.E. 1984. The shell as a recording device: growth record and shell ultrastructure of Lampsilis radiata radiata (Pelecypoda: Unionidae). Can. J. Zool., 62: 2495-2504.

Doherty, F.G., D.W. Evans \& E.F. Neuhauser. 1993. An assessment of total and leachables contaminants in zebra mussels (Dreissena polymorpha) from Lake Eire. Ecotoxicol. Environ. Saf., 25: 328-340.

Ferrington, J.W. E.D. Goldberg. R.W. Risebrough, J.H. Martin \& V.F. Boven. 1983. U.S. Mussel Watch 1976-1978. An overview of the trace metal, DDT, PCB, hydrocarbon and artificial radionuclide data. Environ. Sci. Technol., 17: 490-496.

Förstner, U. \& G.T.W. Wittmann. 1983. Metal Pollution in the Aquatic Environment. Springer Verlag, Berlin: 486 pp.

Furley, T.H. \& A.C. de Oliveira Filho. 2000. Biomonitoring of heavy metals and organo-chlorinated compounds in a pulp mill effluent using mussels. Aquatic Ecosystem Health and Management, 3: 499-507.

Gaggino, G.F. \& E. Cappelletti. 1984. Catasto dei laghi italiani. Vol. I - Italia Settentrionale. Quaderni IRSA$\mathrm{CNR}, \mathrm{n}^{\circ} 72$.

Gaglione, P. \& O. Ravera. 1964. Mn-54 concentration in fallout, water and Unio mussels of Lake Maggiore 19601963. Nature, 204: 1215-1216.

High, K.A., V.J. Barthet, J.W. Laren \& J.S. Blais. 1997. Characterisation of metallothionein-like proteins from zebra mussel (Dreissena polymorpha). Environ. Toxicol. Chem., 16: 1111-1118.

Jeffree, R.A., S.J. Markich \& P.L. Brown. 1993. Comparative accumulation of alkaline earth metals by two freshwater mussel species from the Nepean River, Australia: consistencies and a resolved paradox. Australian J. of Mar. and Freshwat. Res., 44: 609-634.

Johnson, R.K., T. Wiederholm \& D.M. Rosenberg. 1993. Freshwater biomonitoring using individual organisms, populations and species assemblages of benthic macroinvertebrates. In: D.M. Rosenberg \& W.H. Resh (Eds). Freshwater biomonitoring and benthic macroinvertebrates. Chapman and Hall, New York: 40-158.

Langston, W.J., M.J. Bebianno \& G.R. Burt. 1998. Metal handling strategies in molluscs. In: W.J. Langston \& M.J. Bebianno (Eds). Metal Metabolism in Aquatic Environments. Chapman \& Hall, New York: 219-283.

Markich, S.J. \& R.A. Jeffree. 1994. Absorption of divalent trace metals as analogues of calcium by Australian freshwater bivalves: an explanation of how water hardness reduces metal toxicity. Aquat. Toxicol., 29: 257-290. 
Mc Cuaig, J.M. \& R.H. Green. 1983. Unionid growth curves derived from annual rings: a baseline model for Long Point Bay, Lake Erie. Can. J. Fish. Aquat. Sci., 40: 436442.

Merlini, M., F. Girardi, R. Pietra \& A. Brazzelli. 1965. The stable manganese content of molluscs from Lake Maggiore determined by activation analysis. Limnol. Oceanogr., 10: 371-378.

Metcalfe-Smith, J.L. 1994. Influence of species and sex on metal residues in freshwater mussels (family Unionidae) from the St. Lawrence River, with implications for biomonitoring programs. Environ. Toxicol. Chem., 13: 14331443.

Metcalfe-Smith, J.L., R.H. Green, \& L.C. Grabentine. 1996 Influence of biological factors on concentrations of metals in the tissues of freshwater mussels (Elliptio complanato and Lampsilis radiata) from the St. Lawrence River. Can. J. Fish. Aquat. Sci., 53: 205-219.

Millington, P.J. \& K.F. Walker. 1983. Australian freshwater mussel Velesunio ambiguus (Philippi) as a biological monitoring for zinc, iron and manganese. Australian $J$. Mar. Freshwater Res., 34: 873-892.

Mutvei, H. \& T. Westermark. 2001. How environmental information can be obtained from Naiad shells. In: G. Bauer \& K. Wachtler (Eds). Ecology and evolution of the freshwater mussels Unionoida. Springer-Verlag, Berlin. Ecological Studies, 145: 367-379.

Naimo, T.J. 1995. A review of the effects of heavy metals in freshwater mussels. Ecotoxicology, 4: 341-362.

Nelson, D.J. 1964. Deposition of strontium in relation to morphology of clam (Unionidae) shells. Verh. int. Ver. Limnol., 15: 893-902.

Nyström, J. \& E. Dunca. 1996. Nuclear microscopy of freshwater bivalves. Bull. Inst. Océanogr. Monaco Spéc., 14: 121-125.

Nyström, J., E. Dunca, H. Mutvei \& U. Lindh. 1996. Environmental history as reflected by freshwater pearl mussels in the River Vramsån, Southern Sweden. Ambio, 25: 350355 .

O'Connor, T.P., A.Y. Cantillo \& G.G. Lauenstein. 1994. Monitoring of temporal trends in chemical contamination by the NOAA National Status and Trends Mussel Watch Project. In: K.J.M. Kramer (Ed.). Biomonitoring of Coastal Waters and Estuaries. CRC Press, Boca Raton, F1.

Oertel, N. 1998. Molluscs as bioindicators of heavy metals in a side-arm system of the River Danube disturbed by engineering activities. Verh. int. Ver. Limnol., 26: 2120-2124.

Patzner, R.A. \& D. Müller. 2001. Effects of eutrophication on Unionids. In: G. Bauer \& K. Watchtler (Eds). Ecology and evolution of freshwater mussels Unionoida. SpringerVerlag, Berlin. Ecological Studies, 145: 327-335.
Phillips, D.J.H. \& P.S. Rainbow. 1993. Biomonitoring of trace aquatic contaminants. Elsevier, London, U.K.

Popham, J.D. \& J.M. D'Auria. 1983. Combined effect of body size, season and location on trace element levels in mussels (Mytilus edulis). Arch. Environ. Contam. Toxicol., 12: $1-14$.

Pynnönen, K. 1991. Accumulation of Ca-45 in the freshwater unionids Anodonta anatina and Unio tumidus as influenced by water hardness, protons and aluminium. J. Exp. Zool., 260: 18-27.

Ravera, O. 2001. Monitoring of the aquatic environment by species accumulators of pollutants: a review. In: O. Ravera (Ed.), Scientific and legal aspects of biological monitoring in freshwater. J. Limnol., 60 (Suppl.): 63-72.

Ravera, O. \& L. Vido. 1961. Misura del Mn-54 in popolazioni di Unio pictorum, L. (Molluschi, Lamellibranchi) del Lago Maggiore. Mem. Ist. ital. Idrobiol., 13: 75-84.

Ravera, O. \& P. Gaglione. 1962. Concentrazione di Mn-54 da fall-out in relazione all'età e all'organo di Unio mancus elongatulus (Molluschi, Lamellibranchi). Istituto Lombardo (Rend. Sc.), B96: 157-164.

Ravera, O., R. Cenci, G.M. Beone, M. Dantas \& P. Lodigiani. 2003. Trace element concentrations in freshwater mussels and macrophytes as related to those in their environment. J. Limnol., 62(1): 61-70.

Riccardi, N. \& O. Ravera. 1989. Unionidae (Molluscs, Lamellibranchiata) used as an environmental indicator of radioactive contamination from the Chernobyl accident. Environ. Technol. Letters, 10: 347-353.

Roesijadi, G. 1992. Metallothioneins in metal regulation and toxicity in aquatic animals. Aquat. Toxicol., 22: 81-114.

Seed, R. 1968. Factors influencing shell shape in Mytilus edulis, L. J. Mar. Biol. Assoc. U.K., 48: 561-584.

Spry, D.J. \& J.G. Wiener. 1991. Metal bioavailability and toxicity to fish in low alkalinity lakes: a critical review. Environ. Pollut., 71: 243-304.

Strong, C.R. \& S.N. Luoma. 1981. Variations in the correlation of body size with concentrations of $\mathrm{Cu}$ and $\mathrm{Ag}$ in the bivalve Macoma balthica. Can. J. Fish. Aquat. Sci., 38: 1059-1064.

Westermark, T., B. Carell, S. Forberg, H. Mutvei \& E. Kulakowski. 1996. Freshwater unionid (Mollusca: Bivalva) shells as environmental archives: methodology and observations. Bull. Inst. Océanogr. Monaco Spéc., 14: 73-81.

Winner, R.W. 1986. Interactive effects of water hardness and humic acid on the chronic toxicity of cadmium to Daphnia pulex. Aquat. Toxicol., 8: 281:293.

Zamuda, C.D. \& W.G. Sunda. 1982. Bioavailability of dissolved copper to the American oyster Crassostrea virginica. 1. Importance of chemical speciation. Mar. Biol., 66: $77-82$. 